\title{
ZUSES
}

science for a changing world

\section{Estimated Water Use in Washington, 2005}

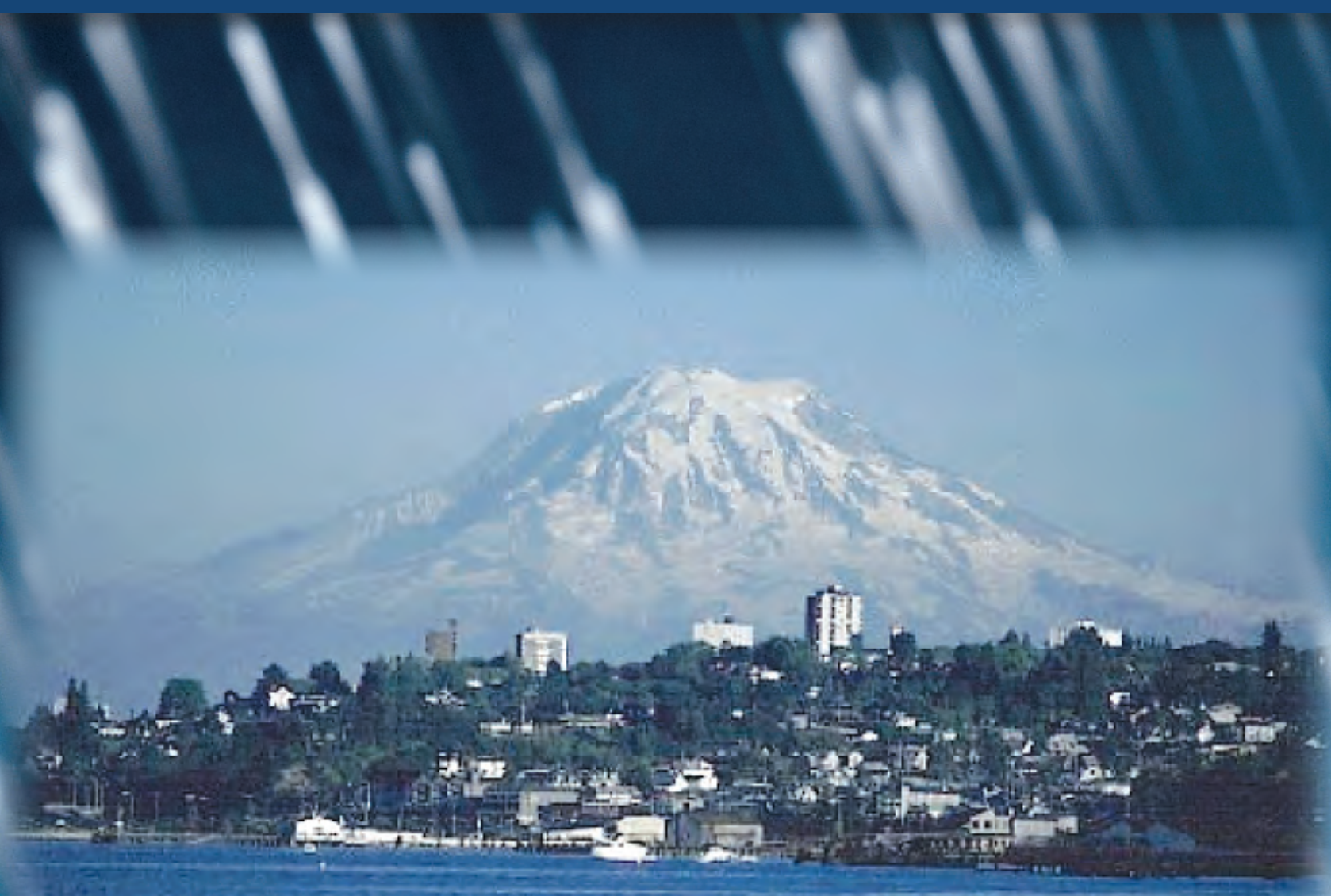

Scientific Investigations Report 2009-5128

U.S. Department of the Interior

U.S. Geological Survey 
Cover: Photograph of Tacoma and Mount Rainier, taken August 20, 1984 by Lyn Topinka, U.S. Geological Survey. 


\section{Estimated Water Use in Washington, 2005}

By R.C. Lane

Scientific Investigations Report 2009-5128

U.S. Department of the Interior

U.S. Geological Survey 


\section{U.S. Department of the Interior \\ KEN SALAZAR, Secretary \\ U.S. Geological Survey \\ Suzette M. Kimball, Acting Director}

U.S. Geological Survey, Reston, Virginia: 2009

For more information on the USGS—-the Federal source for science about the Earth, its natural and living resources,
natural hazards, and the environment, visit http://www.usgs.gov or call 1-888-ASK-USGS
For an overview of USGS information products, including maps, imagery, and publications,
visit http://www.usgs.gov/pubprod
To order this and other USGS information products, visit http://store.usgs.gov

Any use of trade, product, or firm names is for descriptive purposes only and does not imply endorsement by the U.S. Government.

Although this report is in the public domain, permission must be secured from the individual copyright owners to reproduce any copyrighted materials contained within this report.

Suggested citation:

Lane, R.C., 2009, Estimated water use in Washington, 2005: U.S. Geological Survey Scientific Investigations Report 2009-5128, 30 p. 


\section{Contents}

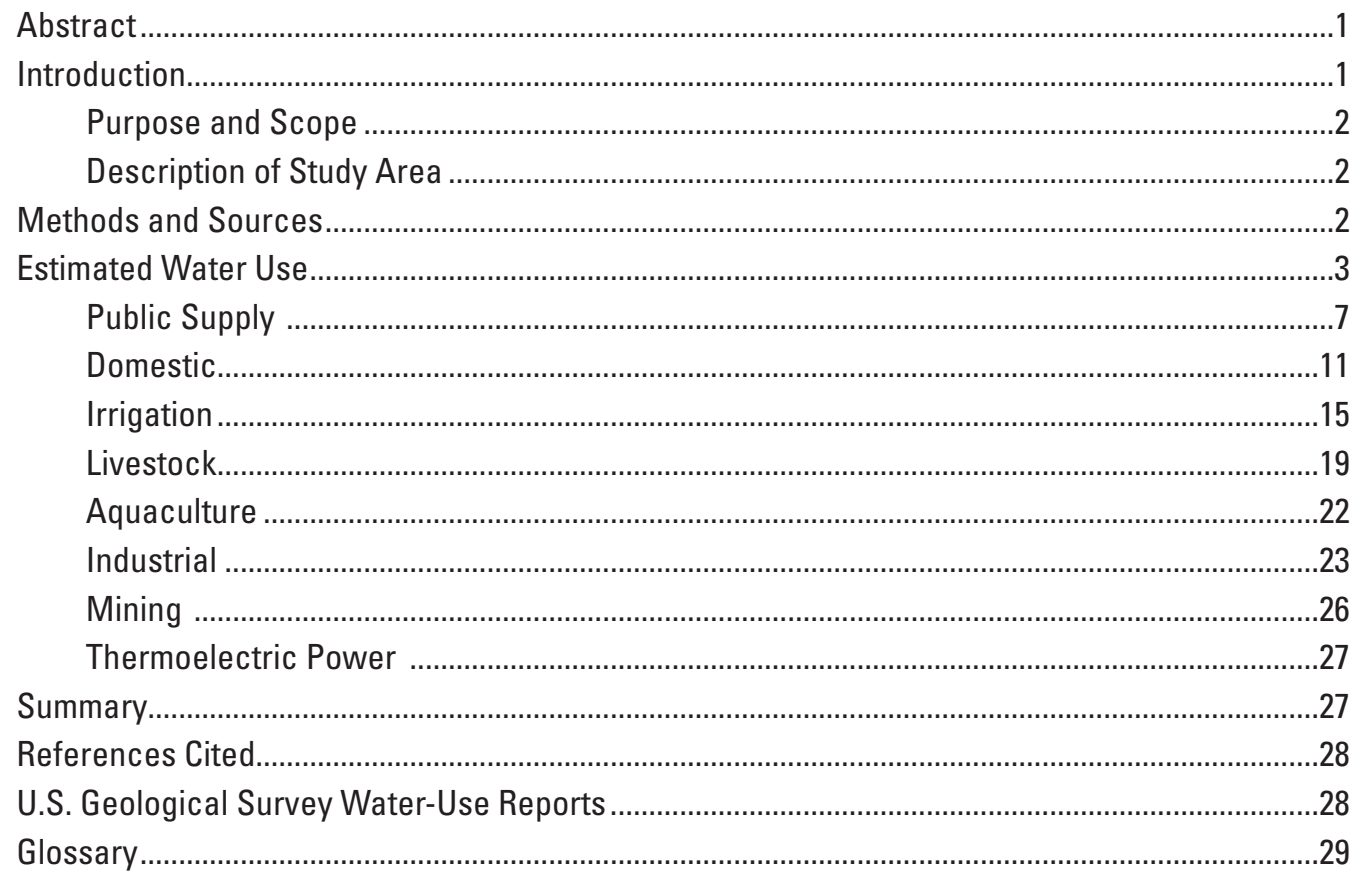

\section{Figures}

Figure 1. Map showing estimated freshwater use, Washington, $2005 \ldots \ldots \ldots \ldots \ldots \ldots \ldots \ldots \ldots$

Figure 2. Map showing estimated freshwater per-capita rates, Washington, $2005 \ldots \ldots \ldots \ldots .6$

Figure 3. Map showing estimated public-supply water use, Washington, $2005 \ldots \ldots \ldots \ldots \ldots .9$

Figure 4. Map showing estimated public-supply per-capita rates, Washington, $2005 \ldots \ldots \ldots 10$

Figure 5. Map showing estimated domestic water use, Washington, $2005 \ldots \ldots \ldots \ldots \ldots \ldots \ldots \ldots$

Figure 6. Map showing estimated domestic per-capita rates, Washington, $2005 \quad \ldots \ldots \ldots \ldots . . .14$

Figure 7. Map showing estimated irrigation water use, Washington, $2005 \ldots \ldots \ldots \ldots \ldots \ldots \ldots \ldots \ldots$

Figure 8. Map showing estimated irrigation application rates, Washington, 2005 ........... 18

Figure 9. Map showing estimated livestock water use, Washington, 2005 ................ 21

Figure 10. Map showing estimated aquaculture water use, Washington, $2005 \ldots \ldots \ldots \ldots \ldots \ldots 22$

Figure 11. Map showing estimated industrial water use, Washington, $2005 \ldots \ldots \ldots \ldots \ldots \ldots \ldots \ldots \ldots$

Figure 12. Map showing estimated mining water use, Washington, $2005 \ldots \ldots \ldots \ldots \ldots \ldots \ldots 26$ 


\section{Tables}

Table 1. Estimated freshwater use, by source and county, Washington, $2005 \quad \ldots \ldots \ldots \ldots . .4$

Table 2. Estimated public-supply water use, by source and county, Washington, $2005 \ldots \ldots .8$

Table 3. Estimated domestic water use, by source and county, Washington, 2005 ........ 12

Table 4. Estimated irrigation water use, by source and county, Washington, 2005......... 16

Table 5. Estimated livestock and aquaculture water use, by source and county, Washington, 2005

Table 6. Estimated industrial and mining water use, by source and county, Washington, 2005

\section{Conversion Factors}

\begin{tabular}{lcl}
\hline \multicolumn{1}{c}{ Multiply } & By & \multicolumn{1}{c}{ To obtain } \\
\hline mile (mi) & Length & \\
& 5,280 & foot $(\mathrm{ft})$ \\
& 1,609 & meter $(\mathrm{m})$ \\
& 1.6093 & kilometer $(\mathrm{km})$ \\
\hline acre & Area & \\
\hline & 43,560 & square foot $\left(\mathrm{ft}^{2}\right)$ \\
& 4,047 & square meter $\left(\mathrm{m}^{2}\right)$ \\
\hline & 0.001562 & square mile $\left(\mathrm{mi}^{2}\right)$ \\
\hline gallon per day (gal/d) & Flow rate & \\
million gallons per day (Mgal/d) & 3.785 & liter per day $(\mathrm{L} / \mathrm{d})$ \\
& 1.121 & thousand acre-feet per year \\
& 0.001547 & thousand cubic feet per second \\
& 0.6944 & thousand gallons per minute \\
& 0.003785 & million cubic meters per day \\
billion gallons per day (Bgal/d) & 1.3815 & million cubic meters per year \\
thousand acre-feet per year & 1.3815 & billion cubic meters per year \\
& 0.8921 & million gallons per day \\
& 0.001380 & thousand cubic feet per second \\
& 0.6195 & thousand gallons per minute \\
& 0.003377 & million cubic meters per day \\
\hline
\end{tabular}

Some water relations in inch-pounds units are shown below:

1 gallon (gal)

1 million gallons (Mgal)

1 cubic foot $\left(\mathrm{ft}^{3}\right)$

1 acre-foot (acre-ft)

1 inch of rain $=\quad 8.34$ pounds

$=\quad 3.07$ acre-feet

$=62.4$ pounds

$=\quad 7.48$ gallons

$=\quad 325,851$ gallons

$=\quad 43,560$ cubic feet

$=\quad 17.4$ million gallons per square mile

$=\quad 27,200$ gallons per acre

$=100$ tons per acre

8




\title{
Estimated Water Use in Washington, 2005
}

\author{
By R.C. Lane
}

\section{Abstract}

Water use in the State of Washington has evolved in the past century from meager domestic and stock water needs to the current complex requirements of domestic-water users, large irrigation projects, industrial plants, and numerous other uses such as fish habitat and recreational activities. Since 1950, the U.S. Geological Survey (USGS) has, at 5-year intervals, compiled data on the amount of water used in homes, businesses, industries, and on farms throughout the State. This water-use data, combined with other related USGS information, has facilitated a unique understanding of the effects of human activity on the State's water resources. As water availability continues to emerge as an important issue in the 21 st century, the need for consistent, long-term water-use data will increase to support wise use of this essential natural resource.

This report presents state and county estimates of the amount of public- and self-supplied water used for domestic, irrigation, livestock, aquaculture, industrial, mining, and thermoelectric power purposes in the State of Washington during 2005. Offstream freshwater use was estimated to be 5,780 million gallons per day (Mgal/d). Domestic water use was estimated to be $648 \mathrm{Mgal} / \mathrm{d}$ or 11 percent of the total. Irrigation water use was estimated to be $3,520 \mathrm{Mgal} / \mathrm{d}$, or 61 percent of the total. Industrial freshwater use was estimated to be $520 \mathrm{Mgal} / \mathrm{d}$, or 9 percent of the total. These three categories accounted for about 81 percent (4,690 Mgal/d) of the total of the estimated offstream freshwater use in Washington during 2005.

\section{Introduction}

Water use in Washington has evolved in the past century from meager domestic and stock water needs to the current complex requirements of domestic-water users, large irrigation projects, industrial plants, and numerous other uses such as fish habitat and recreational activities. Although advances have been made in the ability to control, divert, and develop water supplies, it has been difficult to keep accurate accounts of the actual amounts of water being used. With increasing competition for water (especially during periods of drought), water-use information is of considerable value in determining water availability and in making sound resource-management decisions. Although Washington State is collecting some water-use information, there is currently no statewide program requiring the general reporting of water-use information to the State.

Water-use terminology, as used by the U.S. Geological Survey (USGS), has changed over the years. Terms used in this report are defined in the attached glossary. In the broadest sense water use pertains to the interaction of human activity with the hydrologic cycle, and can be divided into two types, offstream and instream use. Offstream use is the withdrawal or diversion of water from a groundwater or surface-water source for a specific purpose. Instream use is the use of water that remains in the groundwater or surface-water source. Quantitative estimates for most instream uses are undetermined, but are important because such uses compete with offstream uses and affect the quality and quantity of water resources. As used in this report, water use refers only to the estimated offstream use of freshwater for public supply, domestic, irrigation, livestock, aquaculture, industrial, mining, and thermoelectric power purposes in Washington State during 2005, and does not include water used for instream purposes or offstream uses other than those listed. However, these core categories encompass most of known offstream water use in the State. 


\section{Purpose and Scope}

Since 1950, the USGS has, at 5-year intervals, compiled data on the amount of water used in homes, businesses, industries, and on farms throughout Washington State (see section, "U.S. Geological Survey Water-Use Reports"). These reports contain State-level estimates of the amount of public- and self-supplied water used offstream for commercial, domestic, industrial, irrigation, livestock, mining, power generation, and other purposes. This report presents State, regional, and county estimates of the amount of public- and self-supplied water used offstream for domestic, irrigation, livestock, aquaculture, industrial, mining, and thermoelectric power purposes in Washington State during 2005 and describes the methods and sources used to prepare the estimates.

\section{Description of Study Area}

The north-south-trending Cascade Range and the prevailing wind patterns divide Washington State into two regions of distinctly different climate (Dion, 1985; Williams, 1986). Western Washington has a predominantly marine climate with cool, dry summers and mild, wet winters. Precipitation averages about $70 \mathrm{in} / \mathrm{yr}$, but ranges from less than 20 to about $200 \mathrm{in} / \mathrm{yr}$. Potential evaporation ranges from 20 to $25 \mathrm{in} / \mathrm{yr}$, and generally is less than precipitation. Eastern Washington has characteristics of both continental and marine climates, with hot, dry summers and cold, wet winters. Precipitation averages about $20 \mathrm{in} / \mathrm{yr}$, but ranges from less than 7 to about $40 \mathrm{in} / \mathrm{yr}$. Potential evaporation ranges from 25 to $45 \mathrm{in} / \mathrm{yr}$, and generally exceeds precipitation.

\section{Methods and Sources}

Estimates of public-supply water use were based on data from the Washington State Department of Health (WDOH), USGS Washington Water Science Center (WAWSC) and the Washington Department of Ecology (Ecology). A list of all registered public water-supply systems in Washington was obtained from the WDOH on-line database (Washington State Department of Health, 2006). The database contained the names, locations, service populations, and other data for all registered public-water systems in the State. The database did not, however, contain information on water withdrawals and use.

System specific withdrawal and use information were obtained from 483 class A public water-supply systems through the cooperative efforts of the WAWSC and Ecology. The criteria for selecting the individual systems were to provide spatial coverage of each county in the State and to include a representative mix of the municipal, non-municipal, or other types of public-supply systems in the individual counties. The withdrawal and use data from the reporting systems in each county were used to calculate per-capita rates for each of the 483 public-supply systems as follows:

Gross per-capita $=$ Total water withdrawn $/$ population served .

Residential per-capita $=$ Residential use $/$ population served.

For each county, the 25-75 percent trimmed-mean gross per-capita was combined with population and other data for the non-reporting systems to produce the estimates of total public-supplied water in the county. Similarly, the trimmed residential per-capita was used to estimate public-supplied domestic water use values.

Self-supplied domestic use was estimated for each county by using the trimmed residential per capita from the public supply estimates and the self-supplied population of each county from the population estimates. All domestic self-supplied water was assumed to be groundwater except for the small amount of surface water used in Ferry County. For the purposes of this report, the public-supplied domesticuse category includes only those people who are served by a class A public water-supply system. The self-supplied domestic-use category includes those who are self-supplied and those who are served by a class B public water-supply system.

Irrigation water use was estimated as the sum of cropirrigation water use and golf-course-irrigation water use. Cropirrigation acreage and application data for Washington State were not available for the 2005 growing season. Therefore, State and county data for the 2002 growing season (U.S. Department of Agriculture, 2003a, 2003b) were combined with similar county level data from the 2000 Washington water use report (U.S. Geological Survey, 2004) to approximate the 2005 growing season Washington State data. 
Golf-course irrigation estimates were prepared by combining the county golf-course acreage data from the 2000 Washington water use report (U.S. Geological Survey, 2004) with the 2005 crop irrigation application rates from the 2005 compilation.

Estimates of livestock, aquaculture, and mining water use were compiled by the USGS National Water Use Information Office using a variety of sources and methods (John K. Lovelace, U.S. Geological Survey, written commun., 2007). The WAWSC reviewed and accepted the estimates without change.

Estimates of industrial water use were based on similar data from the 2000 Washington water use report (U.S. Geological Survey, 2004), and the change (by county) in the total industrial hours worked from the 1997 and 2002 reports (U.S. Department of Commerce, 2005) using the following equation.

$$
\begin{aligned}
\text { Water.2005 } & =\text { Water.2000 } \\
& \times(\text { Industrial.hours.2005 / Industrial.hours.2000 })
\end{aligned}
$$

The estimate of public-supplied industrial water use was based on data from the USGS inventory of selected publicwater-supply systems discussed under public supply estimates and on similar estimates from the 2000 Washington water use report.

Estimates of water use for thermoelectric power generation were prepared for each individual powergeneration facility in Washington with a nameplate rating of 10 megawatts or more. These estimates were prepared using the following equation.

Water.2005 $=$ Water.2000 $\times($ Power.2005 / Power.2000 $)$

The 2005 power generated data were provided by the National Water Use Information Program (Nancy L. Barber, U.S. Geological Survey, written commun., 2007).

State and county population data from the U.S. Census Bureau were provided by the USGS National Water Use Information Office and are available for on-line at: http:// www.census.gov/popest/datasets.html. Public supplied (class A systems) service population data were obtained from the Washington State Department of Health (WDOH) on-line database (Sentry Internet) and are available on line at: http:// www4.doh.wa.gov/SentryInternet/Intro.aspx. State and county self-supplied domestic population estimates were calculated as the difference between the total county population and the population served by class A public-supply systems. As in past compilations, the self-supplied population figures are actually the sum of the population served by class B public-supply systems and the actual self supplied population.

\section{Estimated Water Use}

Freshwater use in Washington in 2005 was estimated to be about 5,780 Mgal/d (table 1). Surface water accounted for about 74 percent $(4,280 \mathrm{Mgal} / \mathrm{d})$ and groundwater accounted for 26 percent $(1,490 \mathrm{Mgal} / \mathrm{d})$ of the freshwater use in Washington. County-level freshwater use ranged from 1.33 to $1,170 \mathrm{Mgal} / \mathrm{d}$ (fig. 1). The per-capita rate of water use for Washington was estimated to be $919 \mathrm{gal} / \mathrm{d}$ (table 1); the county-level per-capita rates ranged from 120 to $14,400 \mathrm{gal} / \mathrm{d}$ (fig. 2). The large per capita rates for Grant and surrounding counties are due to a combination of large irrigation water use and small populations.

Total saline water use was estimated to be $33.2 \mathrm{Mgal} / \mathrm{d}$, all of which was from saline surface-water sources in western Washington. Nearly all saline water use was for industrial purposes in Pierce (21.4 Mgal/d), Grays Harbor (6.6 Mgal/d), and Jefferson (5.2 Mgal/d) Counties. Various public-supply systems withdrew and desalinized $0.05 \mathrm{Mgal} / \mathrm{d}$ of seawater to augment freshwater supplies. County-level public supply saline-water-use data were not included in this report in order to avoid the discloser of data for individual public watersupply facilities that use saline water. Thus, all subsequent water withdrawal and use information in this report refer to freshwater only. 
Table 1. Estimated freshwater use, by source and county, Washington, 2005.

[Values may not add up to totals because of independent rounding. Per-capita use: Values are total water divided by population]

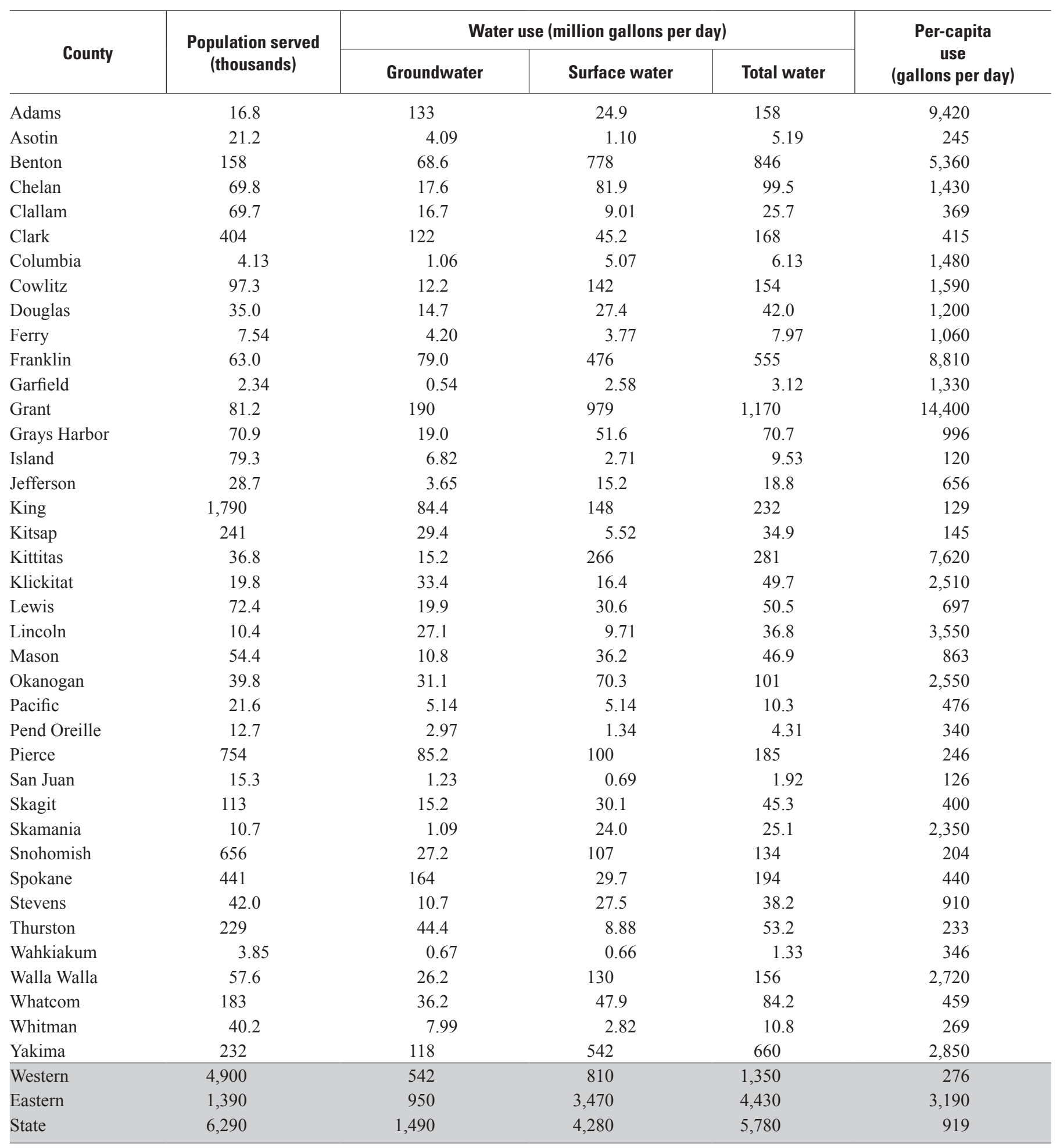




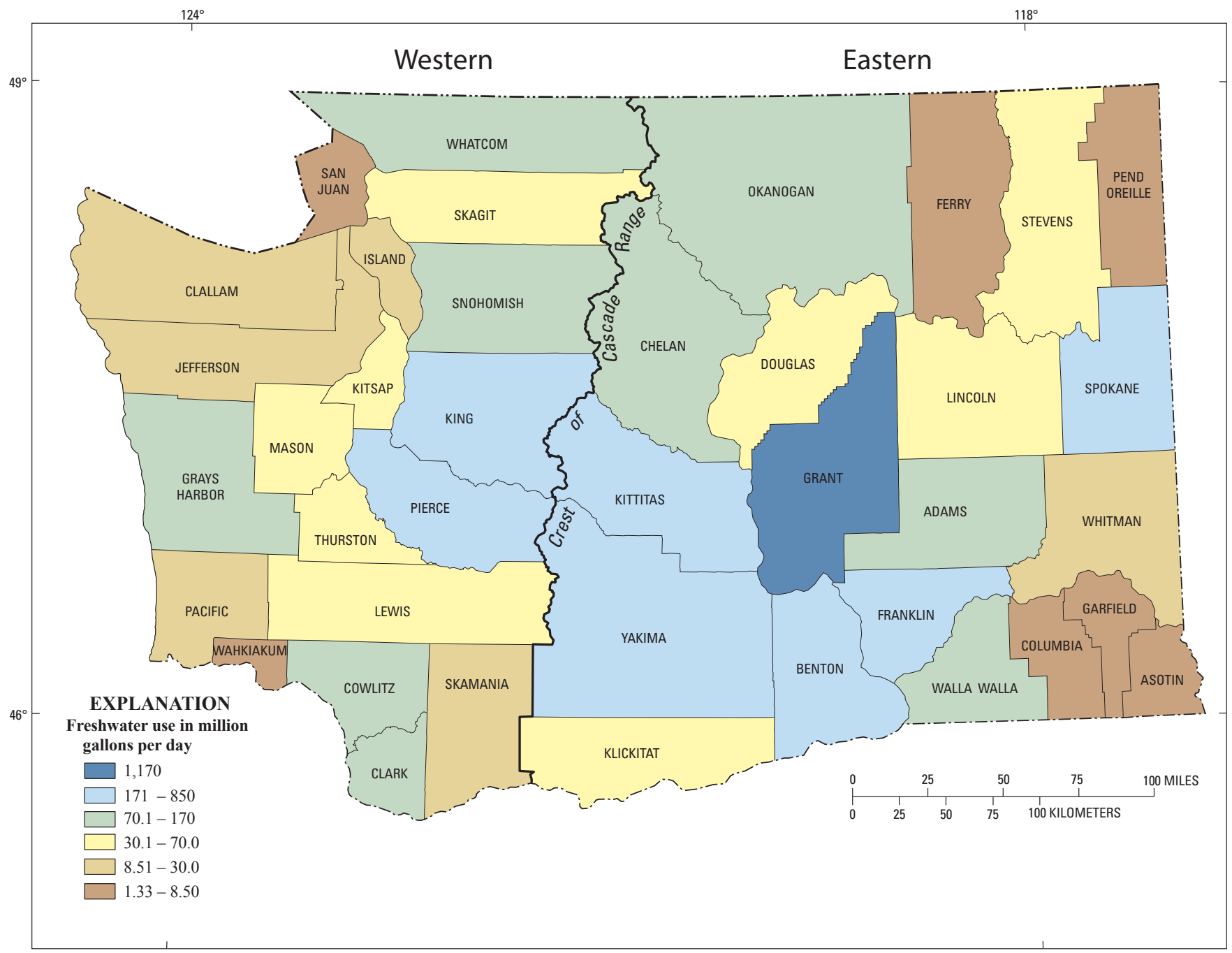

Figure 1. Estimated freshwater use, Washington, 2005. 


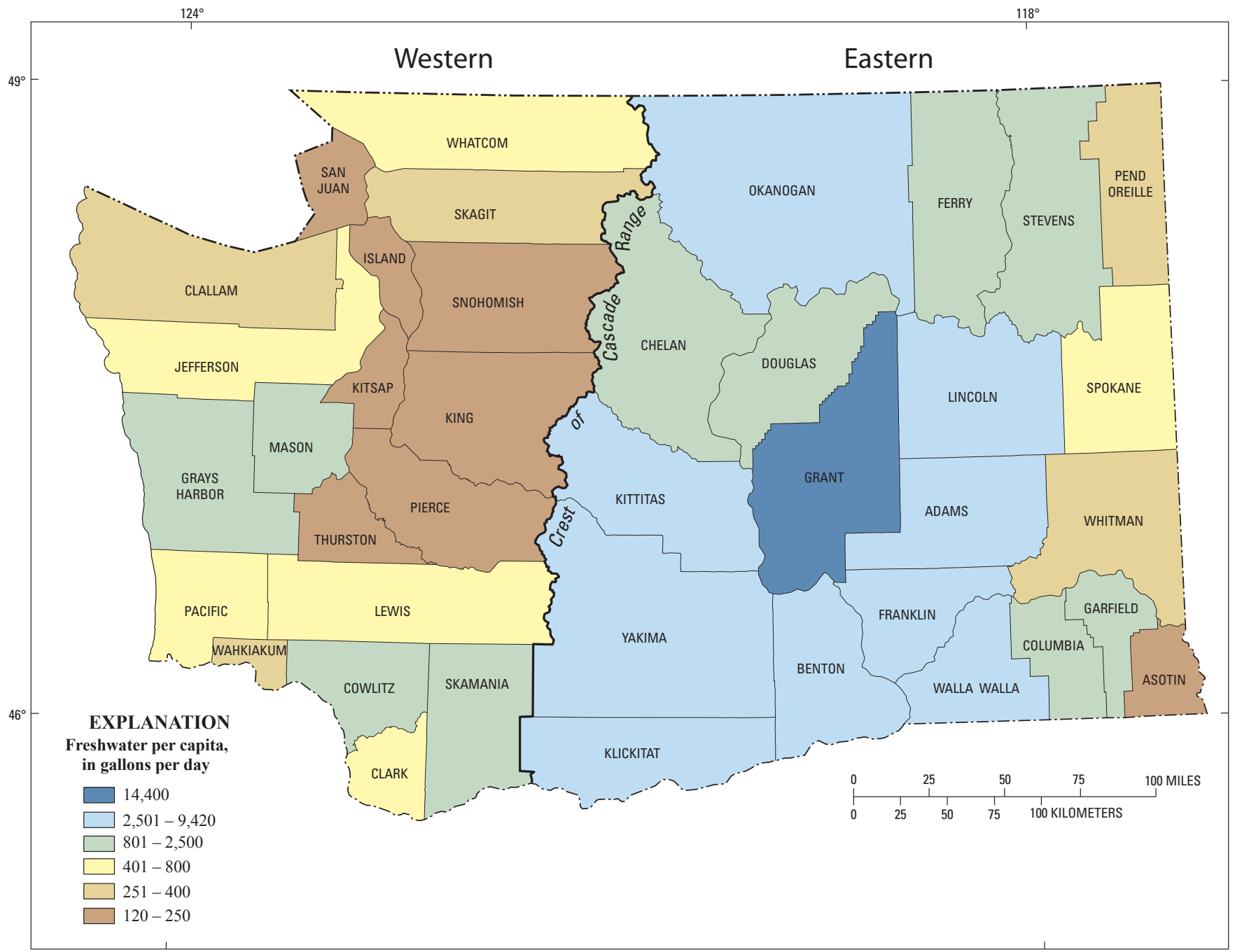

Figure 2. Estimated freshwater per-capita rates, Washington, 2005. 


\section{Public Supply}

Public-supply water use in Washington in 2005 was estimated to total $990 \mathrm{Mgal} / \mathrm{d}$ (table 2), while county-level use ranged from 0.25 to $205 \mathrm{Mgal} / \mathrm{d}$ (fig. 3). Surface water accounted for 46 percent (451 Mgal/d) and groundwater accounted for 54 percent $(539 \mathrm{Mgal} / \mathrm{d}$ ) of the total public-supply water use in the state. The public-supply percapita rate for the state was estimated to be $181 \mathrm{gal} / \mathrm{d}$, with county level rates ranging from 106 to $899 \mathrm{gal} / \mathrm{d}$ (fig. 4). The large per-capita rates for Grays Harbor ( $899 \mathrm{gal} / \mathrm{d}$ ) and Jefferson Counties $(671 \mathrm{gal} / \mathrm{d})$ were due to the use of public-supplied water for industrial and other non-residential purposes.

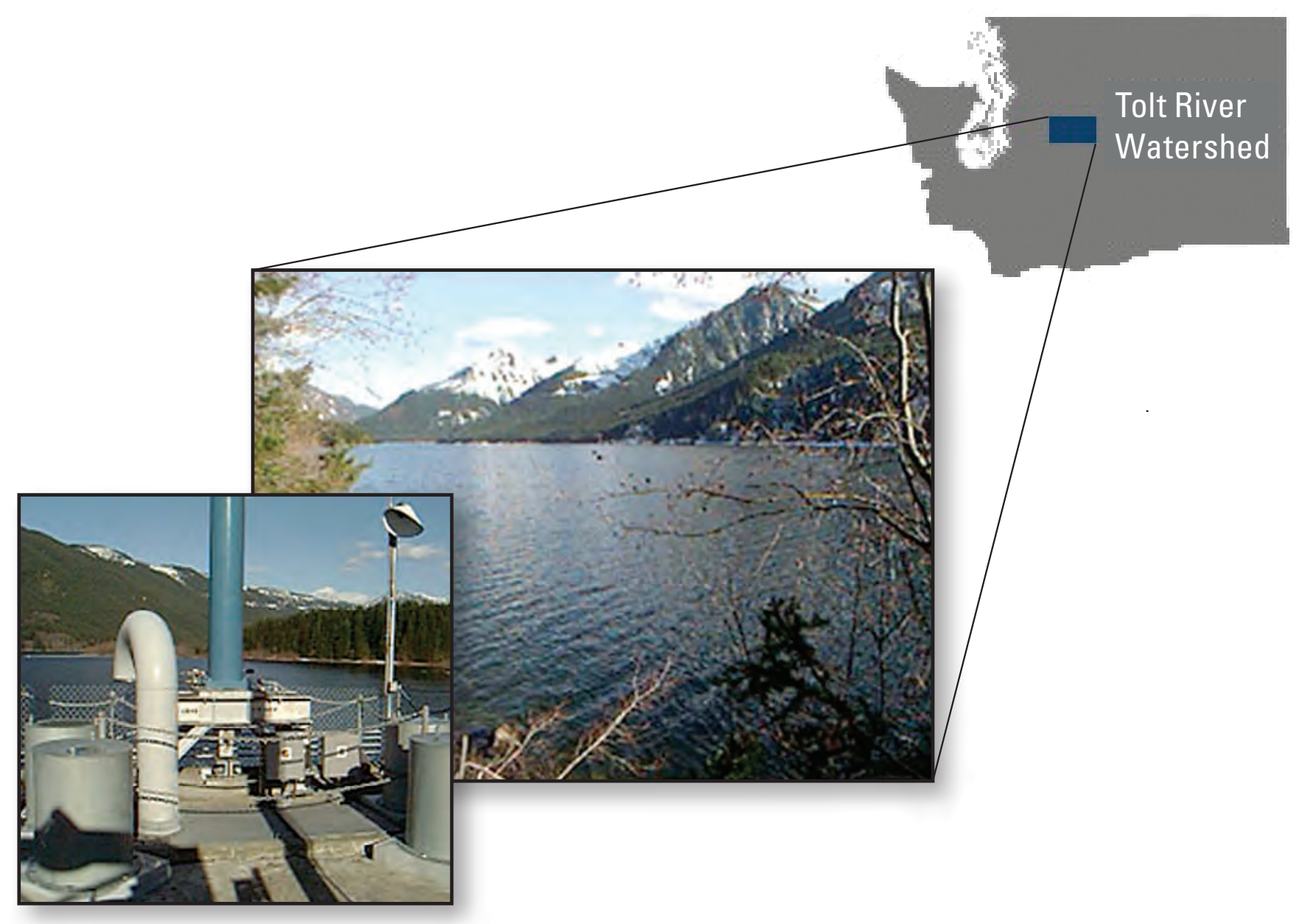

At 1,765 feet above sea level, Tolt Reservoir stores water to be used by the City of Seattle. Photograph courtesy of City of Seattle Public Utilities Department, accessed January 16, 2009, at http://www2.cityofseattle.net/util/tours/ToltVirtualTour/slide14.htm. 
Table 2. Estimated public-supply water use, by source and county, Washington, 2005.

[Values may not add up to totals because of independent rounding. Per-capita use: Values are total water divided by population]

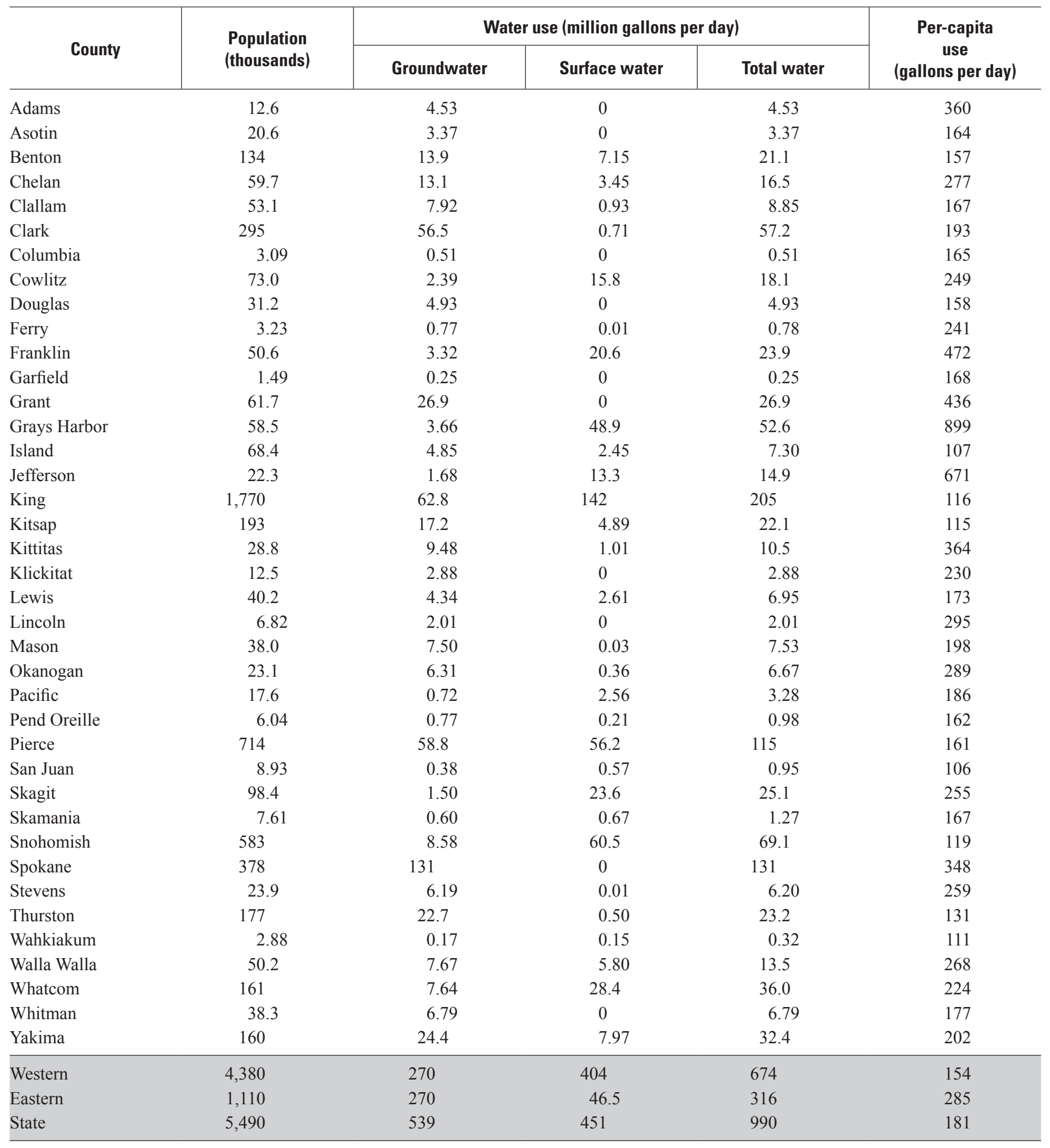




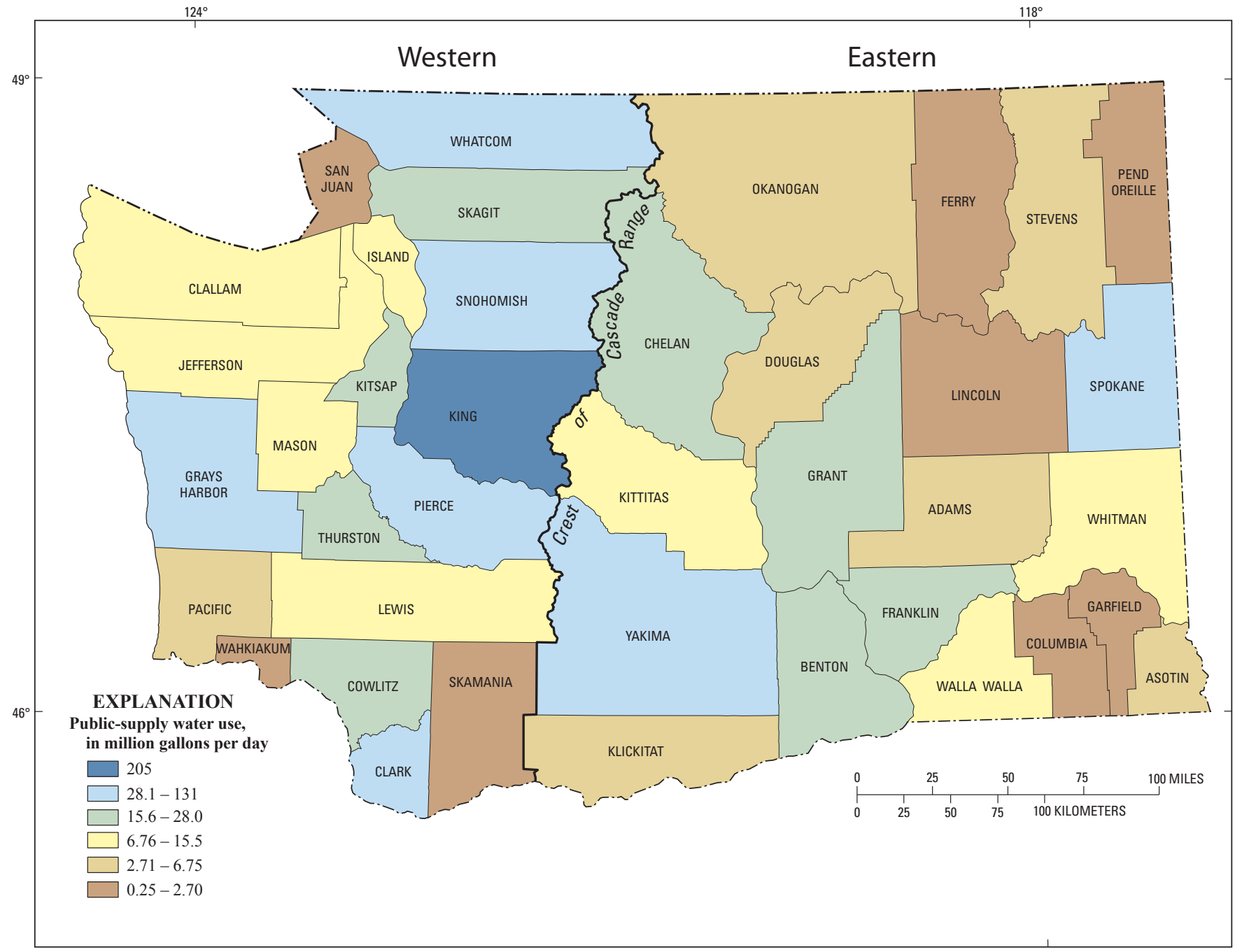

Figure 3. Estimated public-supply water use, Washington, 2005. 


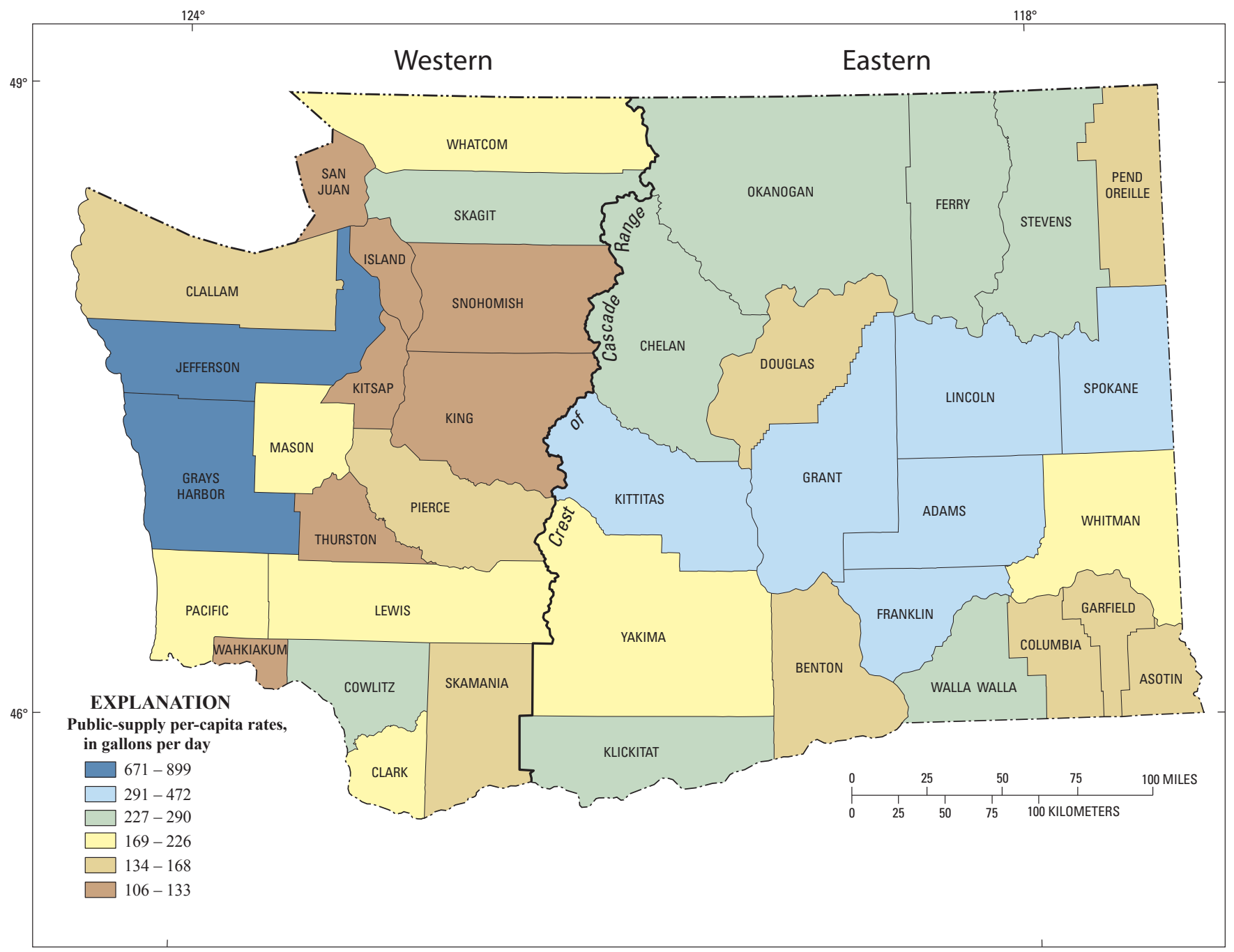

Figure 4. Estimated public-supply per-capita rates, Washington, 2005. 


\section{Domestic}

Domestic water use in Washington for 2005 was estimated to be $648 \mathrm{Mgal} / \mathrm{d}$ (table 3), with county level domestic use ranging from 0.24 to $153 \mathrm{Mgal} / \mathrm{d}$ (fig. 5). Publicsupplied water accounted for 87 percent $(562 \mathrm{Mgal} / \mathrm{d})$ of the total domestic water use in the state, while self-supplied withdrawals of groundwater accounted for almost all of the remaining 13 percent (86.0 Mgal/d). Self-supplied surfacewater withdrawals amounted to only $0.02 \mathrm{Mgal} / \mathrm{d}$. The total domestic per-capita rate for the state was estimated to be $103 \mathrm{gal} / \mathrm{d}$, while county level rates ranged from 72.3 to $210 \mathrm{gal} / \mathrm{d}$ (ig. 6).

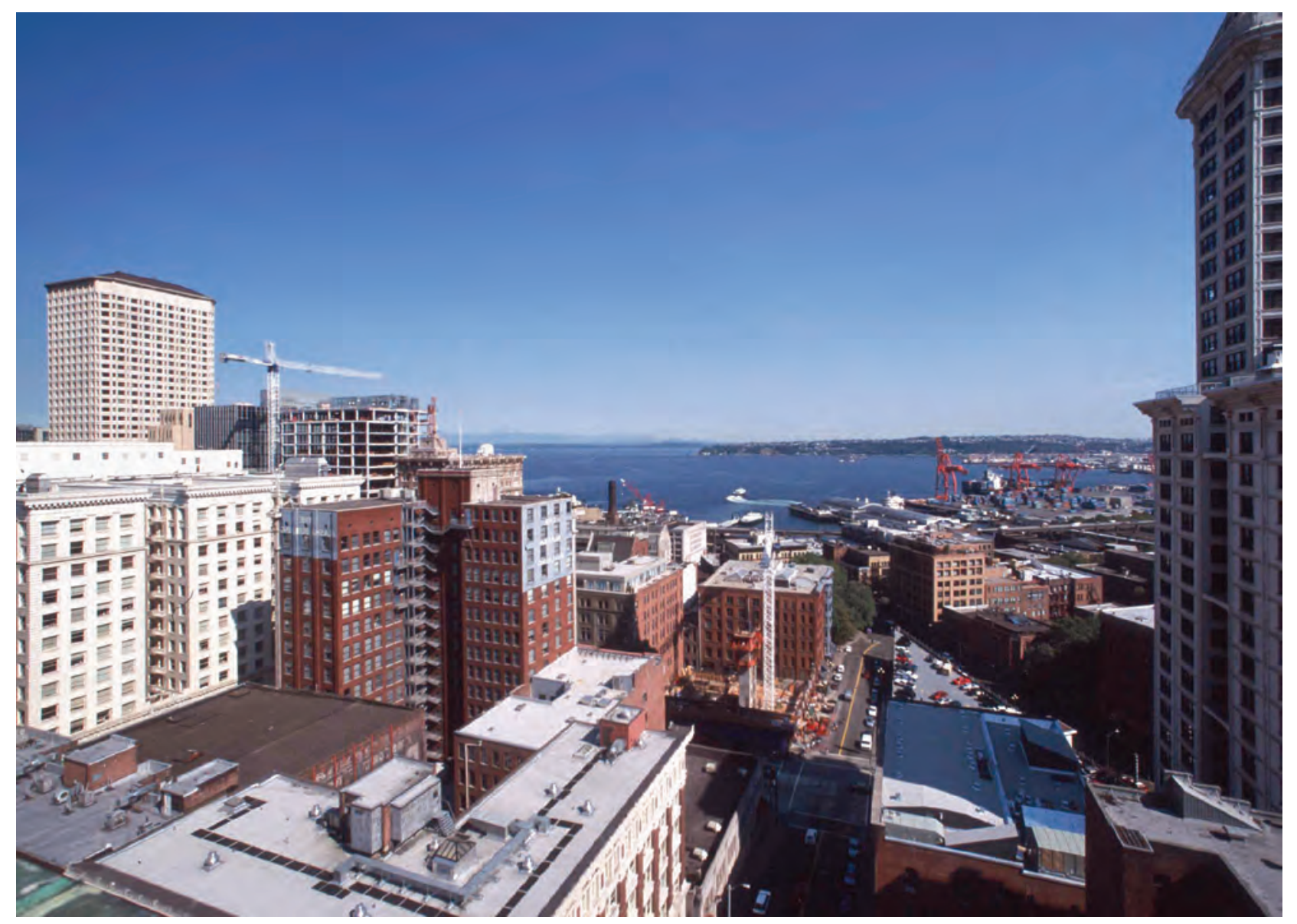

Although usually associated with suburban and rural settings, domestic water use also occurs in urban environments. (Scenic view of downtown Seattle, Washington, with Puget Sound in the background.) Photograph by Gary Wilson, 2000; used with permission of the U.S. Department of Agriculture, National Resources Conservation Service. 
Table 3. Estimated domestic water use, by source and county, Washington, 2005.

[Values may not add up to totals because of independent rounding. Mgal/d, million gallons per day; gal/d, gallons per day]

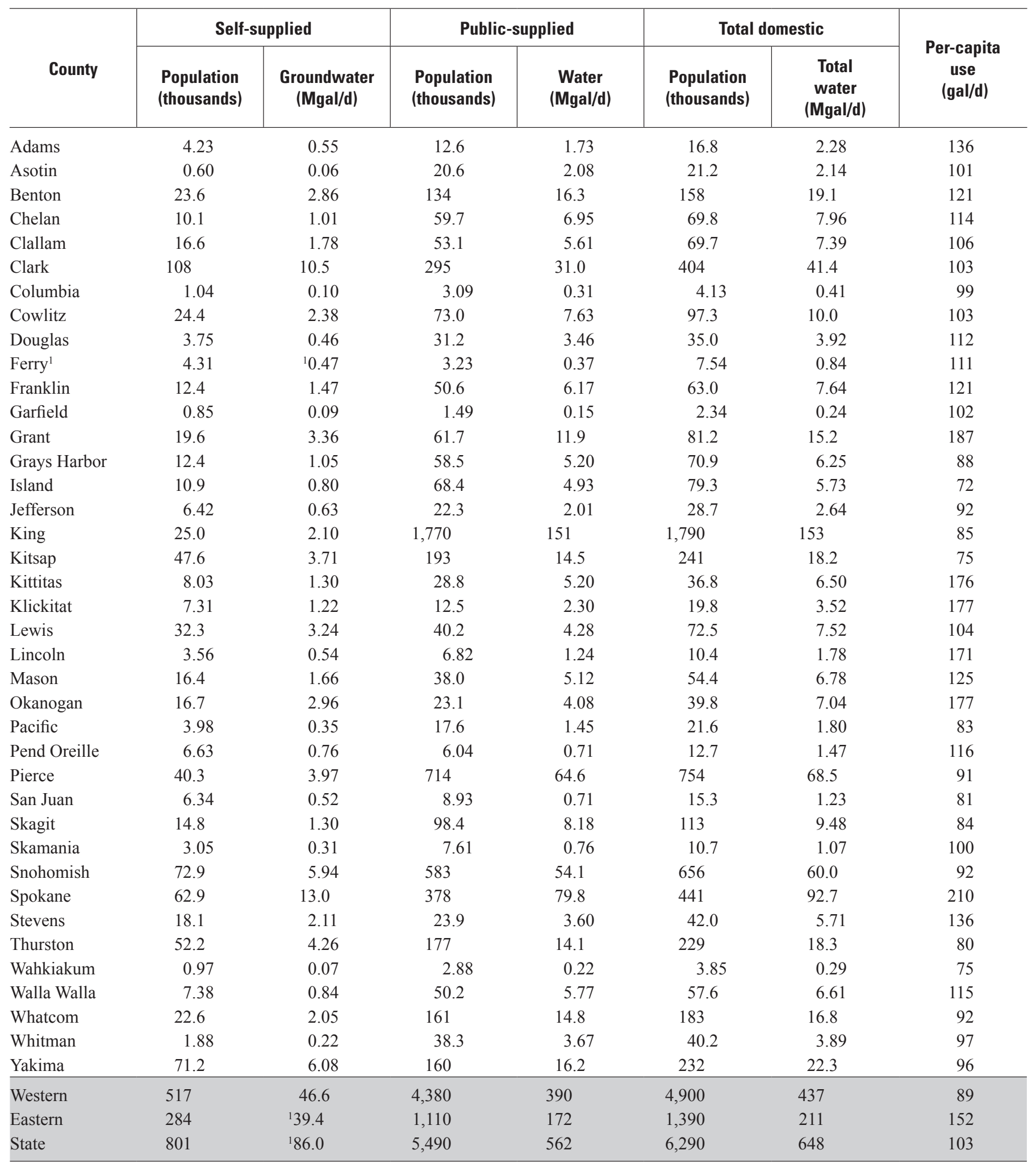

${ }^{1}$ Includes 0.02 million gallons per day of self-supplied surface water. 


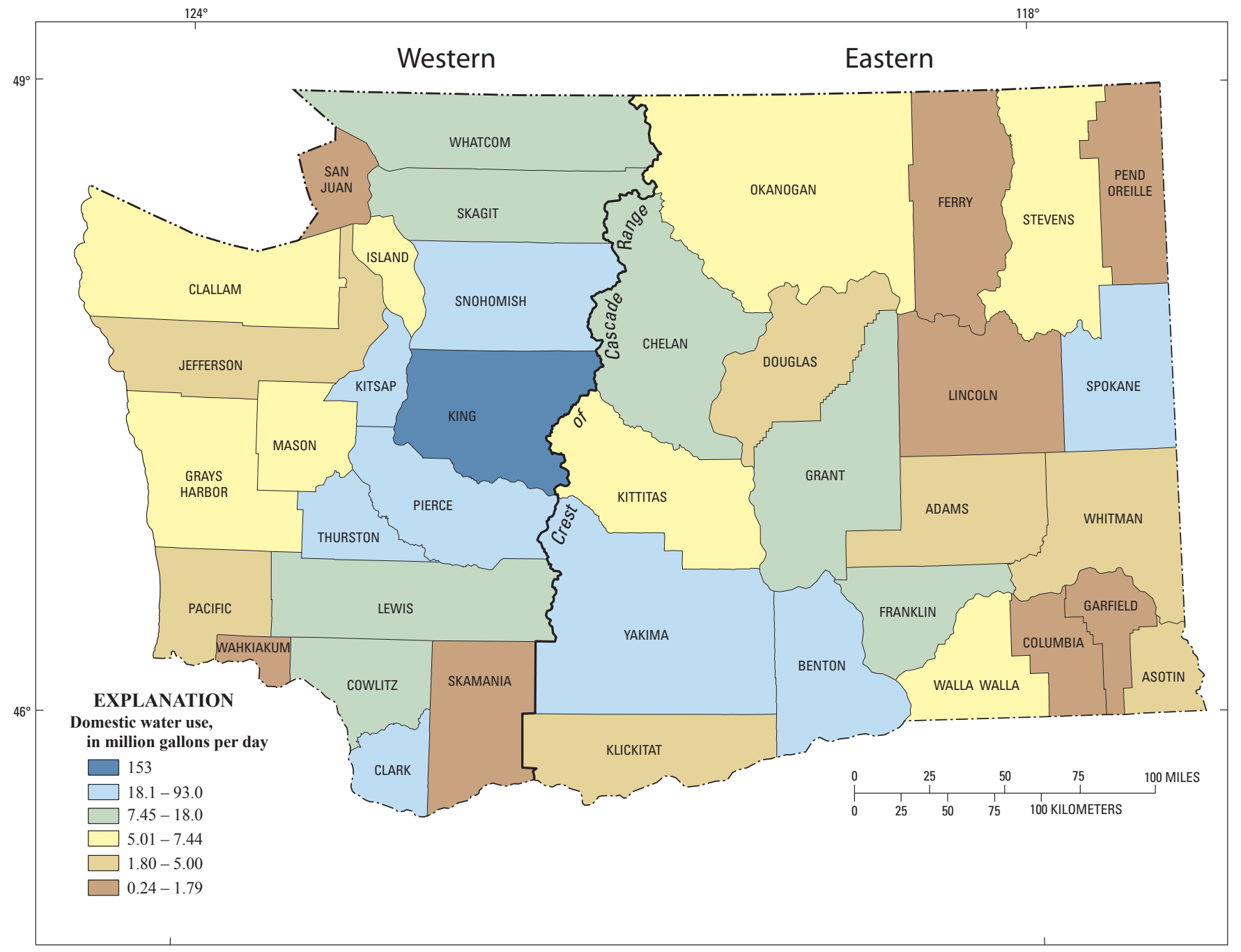

Figure 5. Estimated domestic water use, Washington, 2005. 


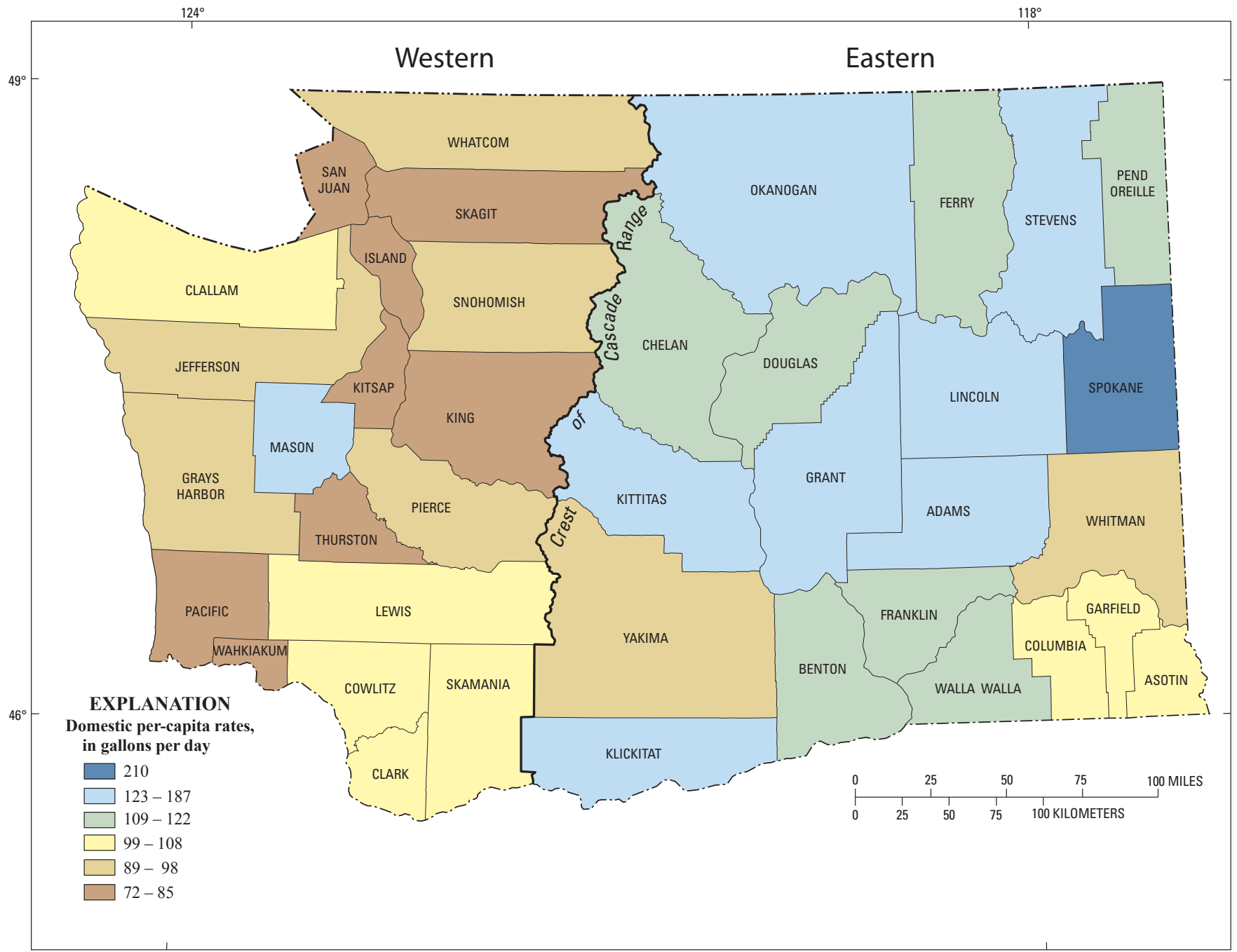

Figure 6. Estimated domestic per-capita rates, Washington, 2005. 


\section{Irrigation}

Irrigation water use in Washington for 2005 was estimated to be 3,950 thousand acre-feet (acre-ft) or about $3,520 \mathrm{Mgal} / \mathrm{d}$ (table 4). County-level irrigation water use was estimated to range from 0.12 to 1,200 thousand acre-ft per year (fig. 7). Surface water accounted for 82 percent $(3,240$ thousand acre-ft) and groundwater accounted for
18 percent (704 thousand acre-ft) of the total irrigation water use in Washington in 2005. The irrigation application rate for Washington was estimated to be 2.14 acre-feet per acre per year (acre-ft/yr) while county-level application rates ranged from 0.27 to 3.25 acre-ft/yr (fig. 8). In terms of acres-irrigated, the five major crops in Washington in 2005 were alfalfa, orchards and vineyards, wheat, potatoes, and hay.

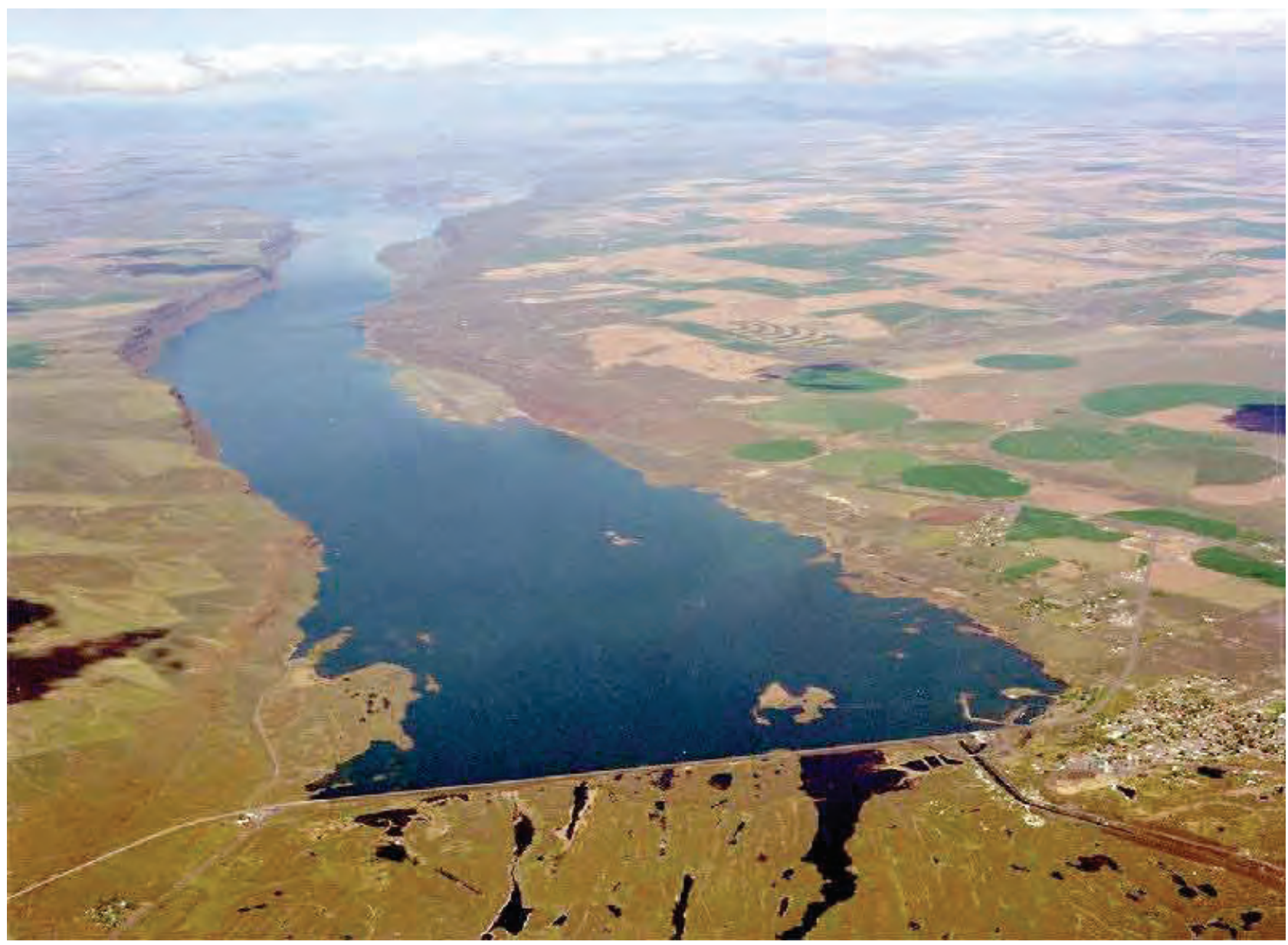

Aerial view of Dry Falls Dam and Banks Lake which provide much of the surface water used to irrigate crops in Washington State. Photograph courtesy of Bureau of Reclamation, accessed January 16, 2009, at http://www.usbr.gov/dataweb/dams/dryfalls2.htm 
Table 4. Estimated irrigation water use, by source and county, Washington, 2005.

[Values may not add up to totals because of independent rounding. Application rate: Values are total water divided by irrigated land. acre-ft/yr, acre-feet per year; (acre-ft/acre)/yr, acre-feet per acre per year]

\begin{tabular}{|c|c|c|c|c|c|c|c|c|}
\hline \multirow{2}{*}{ County } & \multirow{2}{*}{$\begin{array}{l}\text { Irrigated } \\
\text { land } \\
\text { (thousand } \\
\text { acres) }\end{array}$} & \multicolumn{3}{|c|}{$\begin{array}{c}\text { Water use } \\
\text { (million gallons per day) }\end{array}$} & \multicolumn{3}{|c|}{$\begin{array}{c}\text { Water use } \\
\text { (thousand acre-ft/yr) }\end{array}$} & \multirow{2}{*}{$\begin{array}{c}\text { Application } \\
\text { rate } \\
\text { [(acre-ft/ } \\
\text { acre }) / y r]\end{array}$} \\
\hline & & Groundwater & $\begin{array}{c}\text { Surface } \\
\text { water }\end{array}$ & $\begin{array}{c}\text { Total } \\
\text { water }\end{array}$ & Groundwater & $\begin{array}{c}\text { Surface } \\
\text { water }\end{array}$ & $\begin{array}{c}\text { Total } \\
\text { water }\end{array}$ & \\
\hline Adams & 121 & 125 & 24.9 & 150 & 140 & 27.9 & 168 & 1.39 \\
\hline Asotin & 1.88 & 0.22 & 1.00 & 1.22 & 0.25 & 1.12 & 1.37 & 0.73 \\
\hline Benton & 189 & 38.7 & 280 & 318 & 43.4 & 313 & 357 & 1.89 \\
\hline Chelan & 35.1 & 3.48 & 60.3 & 63.8 & 3.90 & 67.5 & 71.5 & 2.04 \\
\hline Clallam & 4.93 & 0.56 & 7.89 & 8.45 & 0.63 & 8.84 & 9.47 & 1.92 \\
\hline Clark & 5.40 & 4.98 & 1.90 & 6.88 & 5.58 & 2.13 & 7.71 & 1.43 \\
\hline Columbia & 2.84 & 0.25 & 3.56 & 3.81 & 0.28 & 3.99 & 4.27 & 1.50 \\
\hline Cowlitz & 3.45 & 0.42 & 3.53 & 3.95 & 0.47 & 3.95 & 4.42 & 1.28 \\
\hline Douglas & 24.3 & 3.55 & 27.3 & 30.9 & 3.98 & 30.6 & 34.6 & 1.42 \\
\hline Ferry & 4.22 & 0.71 & 3.70 & 4.41 & 0.80 & 4.14 & 4.94 & 1.17 \\
\hline Franklin & 241 & 67.6 & 455 & 523 & 75.7 & 510 & 586 & 2.43 \\
\hline Garfield & 0.88 & 0.07 & 0.65 & 0.72 & 0.08 & 0.73 & 0.81 & 0.92 \\
\hline Grant & 494 & 147 & 977 & 1,120 & 165 & 1,090 & 1,260 & 2.55 \\
\hline Grays Harbor & 5.56 & 3.22 & 2.52 & 5.74 & 3.61 & 2.82 & 6.43 & 1.16 \\
\hline Island & 1.51 & 0.78 & 0.24 & 1.02 & 0.87 & 0.27 & 1.14 & 0.76 \\
\hline Jefferson & 0.95 & 0.73 & 0.52 & 1.25 & 0.82 & 0.58 & 1.40 & 1.47 \\
\hline King & 7.28 & 3.50 & 3.48 & 6.98 & 3.92 & 3.90 & 7.82 & 1.07 \\
\hline Kitsap & 1.40 & 0.99 & 0.52 & 1.51 & 1.11 & 0.58 & 1.69 & 1.21 \\
\hline Kittitas & 92.1 & 2.76 & 264 & 267 & 3.09 & 296 & 299 & 3.25 \\
\hline Klickitat & 25.4 & 19.6 & 14.8 & 34.4 & 21.9 & 16.6 & 38.5 & 1.52 \\
\hline Lewis & 9.61 & 4.73 & 5.67 & 10.4 & 5.30 & 6.35 & 11.7 & 1.22 \\
\hline Lincoln & 44.4 & 24.2 & 9.61 & 33.9 & 27.1 & 10.8 & 37.9 & 0.85 \\
\hline Mason & 1.11 & 0.90 & 0.29 & 1.19 & 1.01 & 0.32 & 1.33 & 1.20 \\
\hline Okanogan & 48.5 & 18.8 & 60.8 & 79.6 & 21.0 & 68.1 & 89.1 & 1.84 \\
\hline Pacific & 2.95 & 0.93 & 2.12 & 3.05 & 1.04 & 2.37 & 3.42 & 1.16 \\
\hline Pend Oreille & 1.43 & 0.23 & 0.47 & 0.70 & 0.26 & 0.53 & 0.78 & 0.55 \\
\hline Pierce & 8.14 & 6.46 & 2.80 & 9.26 & 7.24 & 3.14 & 10.4 & 1.27 \\
\hline San Juan & 0.45 & 0.02 & 0.09 & 0.11 & 0.02 & 0.10 & 0.12 & 0.27 \\
\hline Skagit & 18.1 & 11.3 & 4.56 & 15.8 & 12.6 & 5.11 & 17.7 & 0.98 \\
\hline Skamania & 0.68 & 0.18 & 0.55 & 0.73 & 0.20 & 0.62 & 0.82 & 1.20 \\
\hline Snohomish & 7.26 & 2.47 & 3.11 & 5.58 & 2.77 & 3.48 & 6.25 & 0.86 \\
\hline Spokane & 13.6 & 10.3 & 2.06 & 12.3 & 11.5 & 2.31 & 13.8 & 1.02 \\
\hline Stevens & 11.7 & 1.75 & 10.4 & 12.2 & 1.96 & 11.6 & 13.6 & 1.17 \\
\hline Thurston & 7.31 & 5.97 & 2.32 & 8.29 & 6.69 & 2.60 & 9.29 & 1.27 \\
\hline Wahkiakum & 0.52 & 0.22 & 0.42 & 0.64 & 0.25 & 0.47 & 0.72 & 1.38 \\
\hline Walla Walla & 93.6 & 17.0 & 114 & 131 & 19.0 & 128 & 147 & 1.57 \\
\hline Whatcom & 33.1 & 21.5 & 9.14 & 30.7 & 24.1 & 10.2 & 34.4 & 1.04 \\
\hline Whitman & 6.34 & 0.75 & 2.80 & 3.55 & 0.84 & 3.14 & 3.98 & 0.63 \\
\hline Yakima & 270 & 77.0 & 529 & 606 & 86.2 & 593 & 679 & 2.52 \\
\hline Western & 120 & 69.9 & 51.7 & 122 & 78.3 & 57.9 & 136 & 1.14 \\
\hline Eastern & 1,720 & 559 & 2,840 & 3,400 & 626 & 3,180 & 3,810 & 2.21 \\
\hline State & 1,840 & 629 & 2,890 & 3,520 & 704 & 3,240 & 3,950 & 2.14 \\
\hline
\end{tabular}




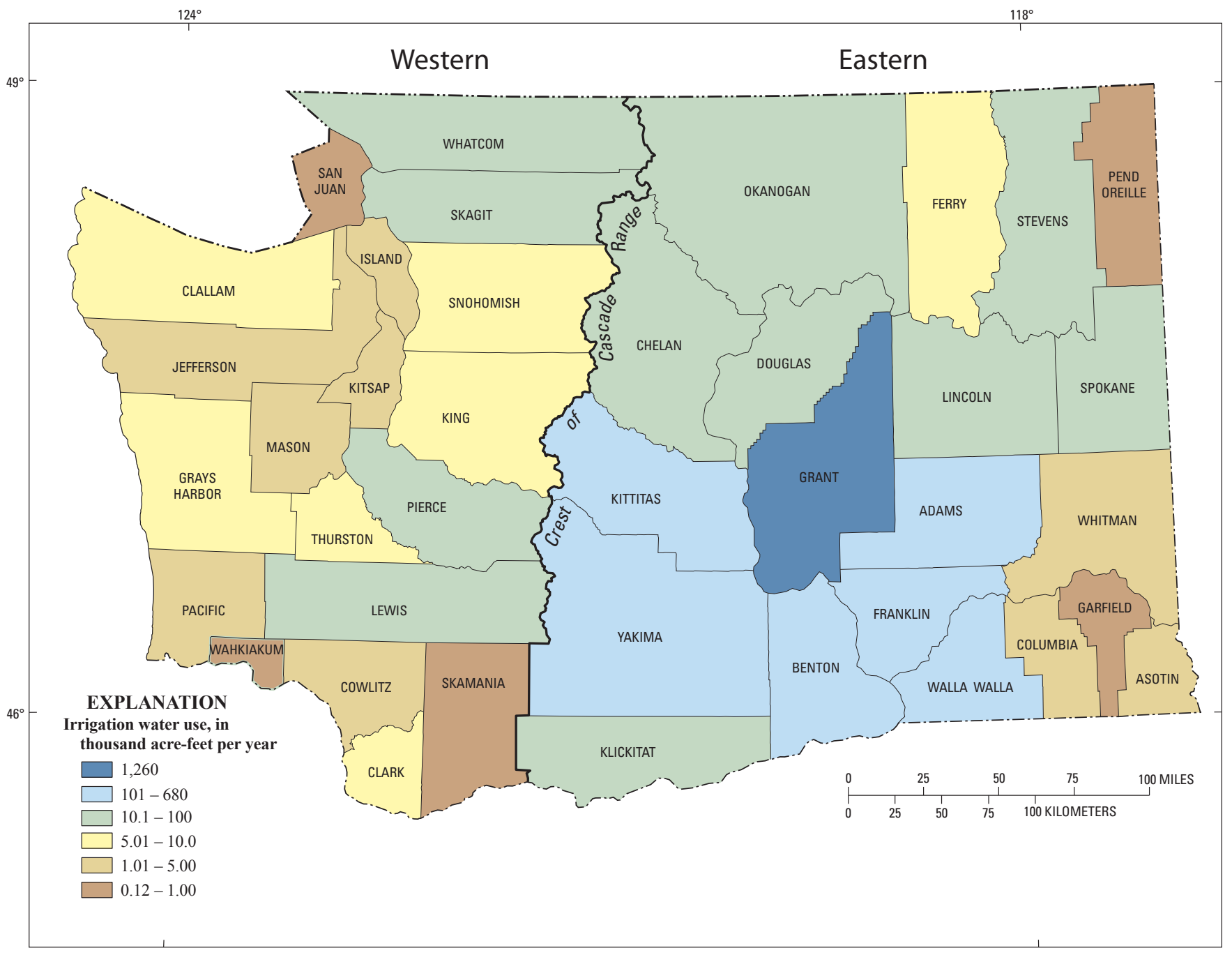

Figure 7. Estimated irrigation water use, Washington, 2005. 


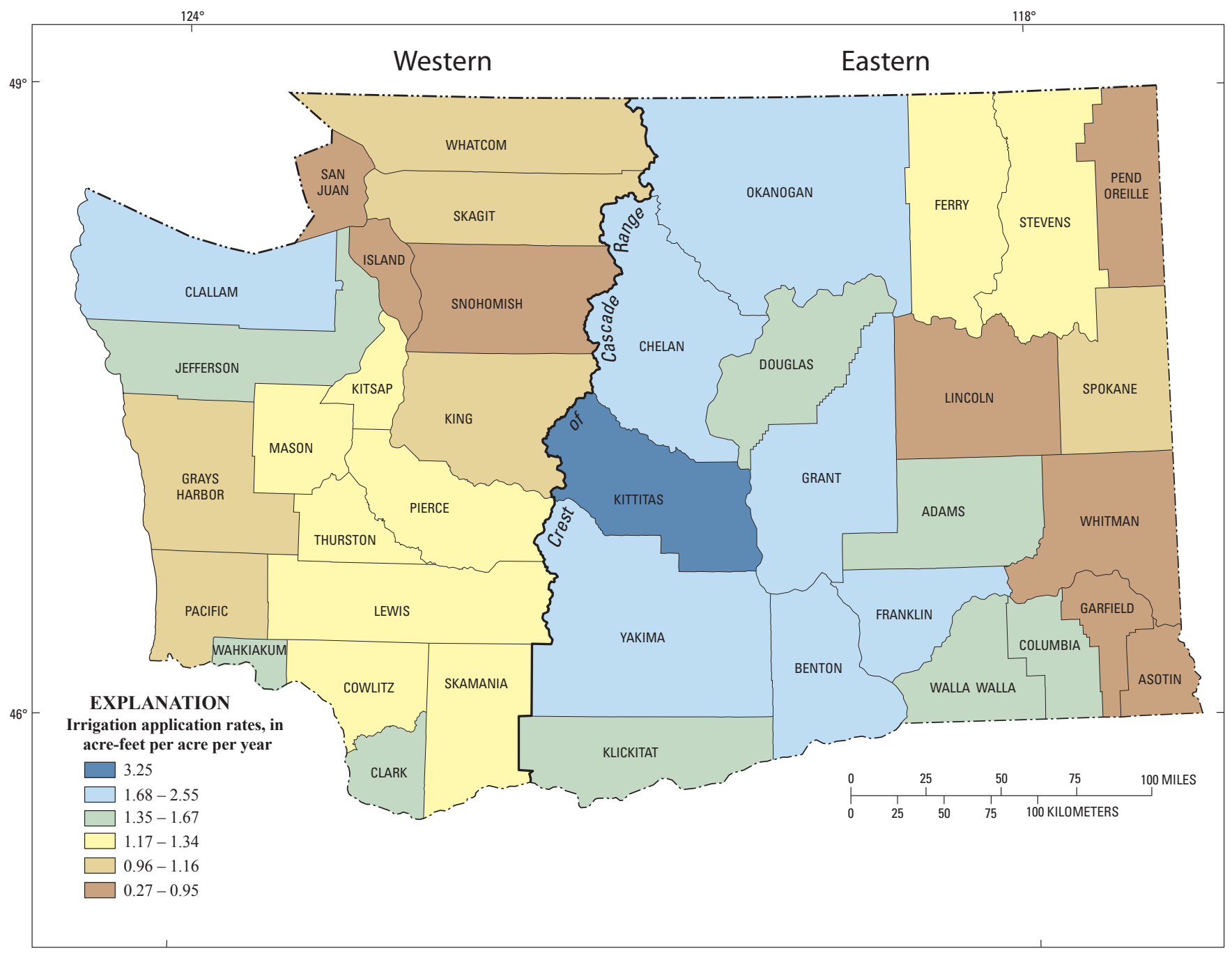

Figure 8. Estimated irrigation application rates, Washington, 2005. 


\section{Livestock}

Livestock water use in Washington for 2005 was estimated to be $30.7 \mathrm{Mgal} / \mathrm{d}$ (table 5) and county-level water use was estimated to range from 0.01 to $7.15 \mathrm{Mgal} / \mathrm{d}$ (fig. 9). Surface water accounted for 32 percent $(9.82 \mathrm{Mgal} / \mathrm{d})$ and groundwater accounted for 68 percent $(20.9 \mathrm{Mgal} / \mathrm{d})$ of the total livestock water use in the State. Dairy and beef cattle accounted for almost all of the livestock water use in Washington, although most of the other farm animal groups were represented in the State.

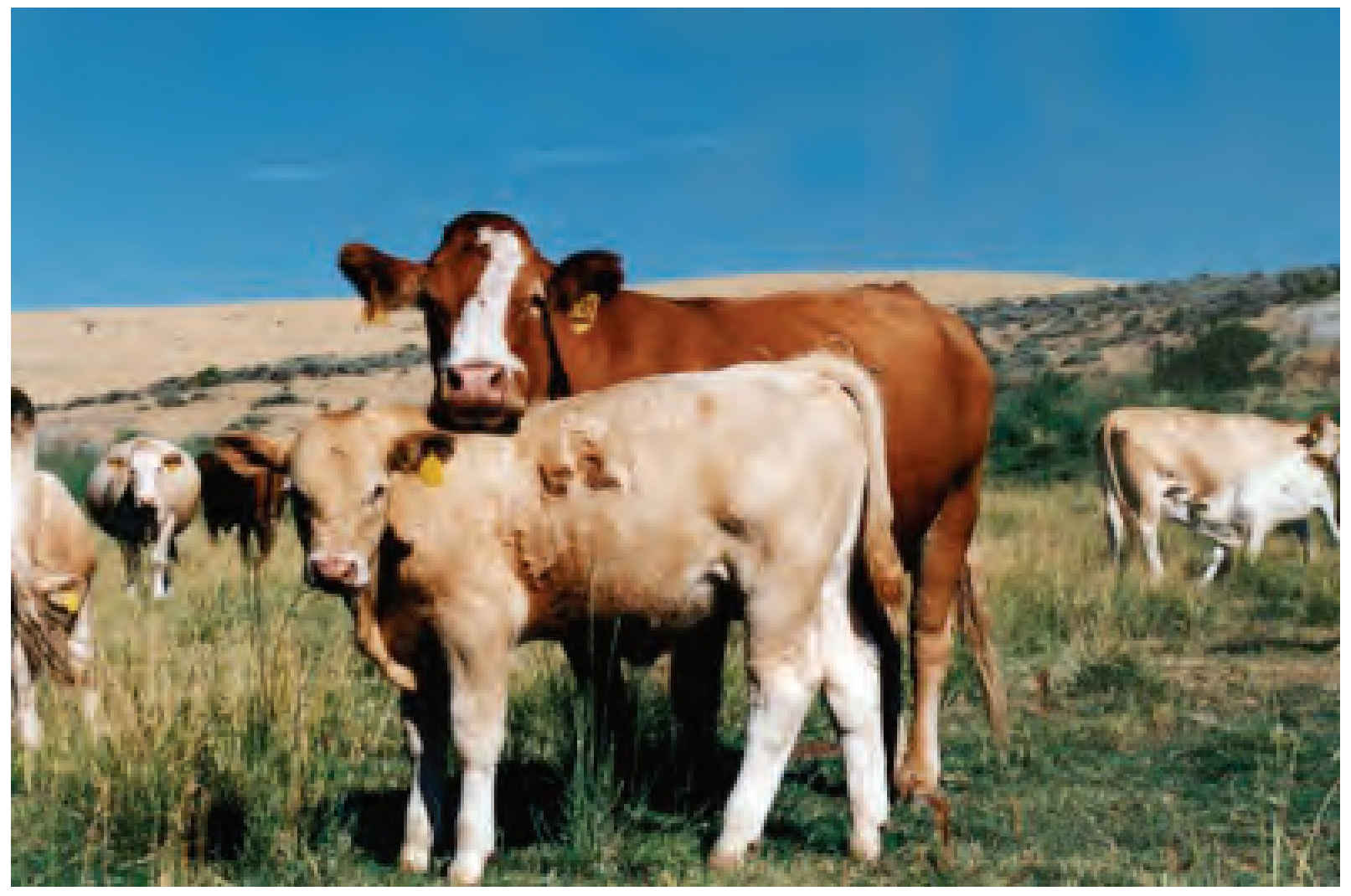

Although most major farm animal groups are represented in Washington, the rearing of cattle for meat and dairy products continues to dominate the Livestock Water Use Category. Photograph courtesy of the Washington State Department of Agriculture, Livestock Brand Inspection Program. Access January 23, 2009, at http://agr.wa.gov/foodanimal/livestock/default.aspx 
Table 5. Estimated livestock and aquaculture water use, by source and county, Washington, 2005.

[Values may not add up to total due to independent rounding. All values in million gallons per day]

\begin{tabular}{|c|c|c|c|c|c|c|}
\hline \multirow{2}{*}{ County } & \multicolumn{3}{|c|}{ Livestock } & \multicolumn{3}{|c|}{ Aquaculture } \\
\hline & Groundwater & Surface water & Total water & Groundwater & Surface water & Total water \\
\hline Asotin & 0.09 & 0.04 & 0.13 & 0 & 0 & 0 \\
\hline Benton & 0.48 & 0.05 & 0.53 & 2.40 & 1.20 & 3.60 \\
\hline Chelan & 0.01 & 0.03 & 0.04 & 0 & 8.34 & 8.34 \\
\hline Clark & 0.40 & 0.11 & 0.51 & 2.16 & 0 & 2.16 \\
\hline Columbia & 0.06 & 0.02 & 0.08 & 0 & 1.47 & 1.47 \\
\hline Cowlitz & 0.11 & 0.03 & 0.14 & 6.71 & 0 & 6.71 \\
\hline Douglas & 0.11 & 0.04 & 0.15 & 3.09 & 0 & 3.09 \\
\hline Ferry & 0.09 & 0.03 & 0.12 & 1.98 & 0 & 1.98 \\
\hline Island & 0.14 & 0.02 & 0.16 & 0 & 0 & 0 \\
\hline Jefferson & 0.10 & 0 & 0.10 & 0 & 1.37 & 1.37 \\
\hline King & 1.00 & 0.08 & 1.08 & 7.78 & 0 & 7.78 \\
\hline Kitsap & 0.02 & 0.02 & 0.04 & 6.92 & 0 & 6.92 \\
\hline Kittitas & 0.24 & 0.23 & 0.47 & 0 & 0 & 0 \\
\hline Klickitat & 0.20 & 0.14 & 0.34 & 9.18 & 0 & 9.18 \\
\hline Lewis & 0.76 & 0.35 & 1.11 & 3.36 & 0 & 3.36 \\
\hline Lincoln & 0.23 & 0.08 & 0.31 & 0 & 0 & 0 \\
\hline Mason & 0.02 & 0.02 & 0.04 & 0 & 27.4 & 27.4 \\
\hline Okanogan & 0.51 & 0.10 & 0.61 & 0 & 9.03 & 9.03 \\
\hline Snohomish & 0.76 & 0.73 & 1.49 & 6.63 & 0.04 & 6.67 \\
\hline Spokane & 0.54 & 0.01 & 0.55 & 1.07 & 1.07 & 2.14 \\
\hline Stevens & 0.32 & 0.24 & 0.56 & 0 & 8.69 & 8.69 \\
\hline Thurston & 0.64 & 0.43 & 1.07 & 5.79 & 5.31 & 11.1 \\
\hline Wahkiakum & 0.04 & 0.04 & 0.08 & 0.02 & 0.03 & 0.05 \\
\hline Walla Walla & 0.20 & 0.12 & 0.32 & 0 & 0 & 0 \\
\hline Whatcom & 3.06 & 2.24 & 5.30 & 1.46 & 1.46 & 2.92 \\
\hline Whitman & 0.23 & 0.02 & 0.25 & 0 & 0 & 0 \\
\hline Yakima & 4.28 & 2.87 & 7.15 & 0.03 & 1.74 & 1.77 \\
\hline Western & 8.78 & 5.23 & 14.0 & 59.3 & 89.0 & 148 \\
\hline Eastern & 12.1 & 4.59 & 16.7 & 27.4 & 35.1 & 62.5 \\
\hline State & 20.9 & 9.82 & 30.7 & 86.7 & 124 & 211 \\
\hline
\end{tabular}




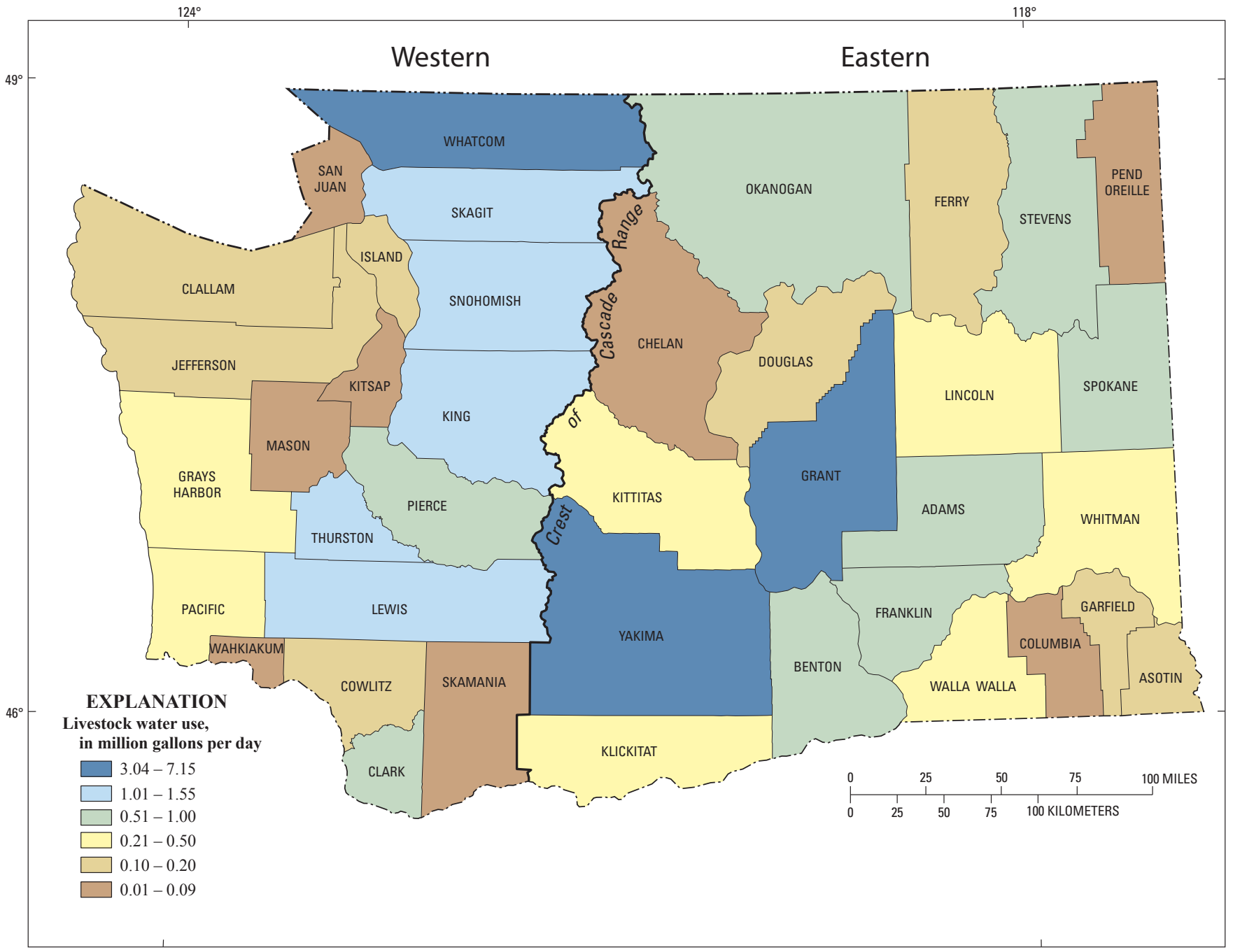

Figure 9. Estimated livestock water use, Washington, 2005. 


\section{Aquaculture}

Aquaculture water use in Washington for 2005 was estimated to be $211 \mathrm{Mgal} / \mathrm{d}$ (table 5), while county-level water use was estimated to range from 0.05 to $36.8 \mathrm{Mgal} / \mathrm{d}$ (fig. 10 ). Surface water accounted for 59 percent (124 Mgal/d) and groundwater for the remaining 41 percent $(86.7 \mathrm{Mgal} / \mathrm{d})$ of the total State use. Water used in the rearing of salmon and trout in fish hatcheries comprised most of the aquaculture water use in Washington in 2005.

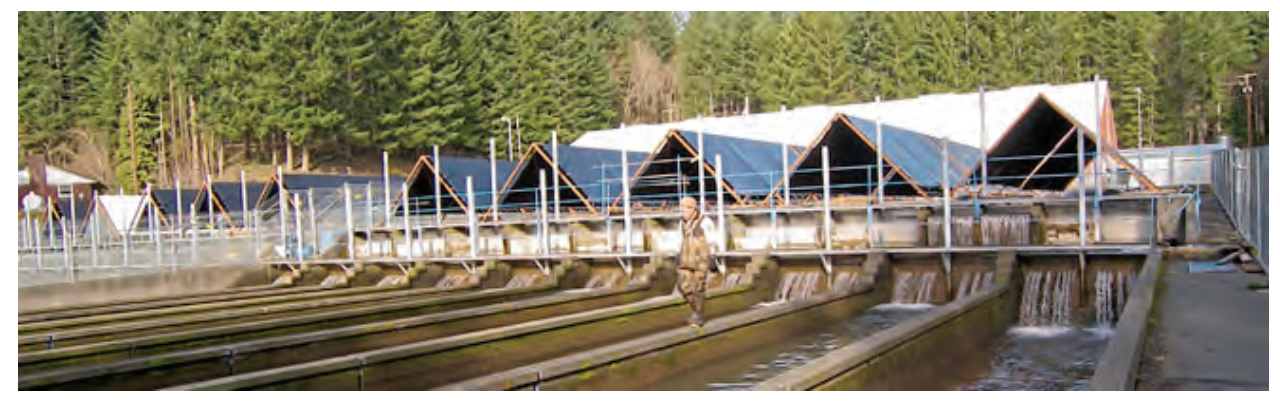

Covered raceways at Willard National Fish Hatchery used in the rearing of Coho salmon. Photograph by C. Anderson, courtesy of Willard National Fish Hatchery.

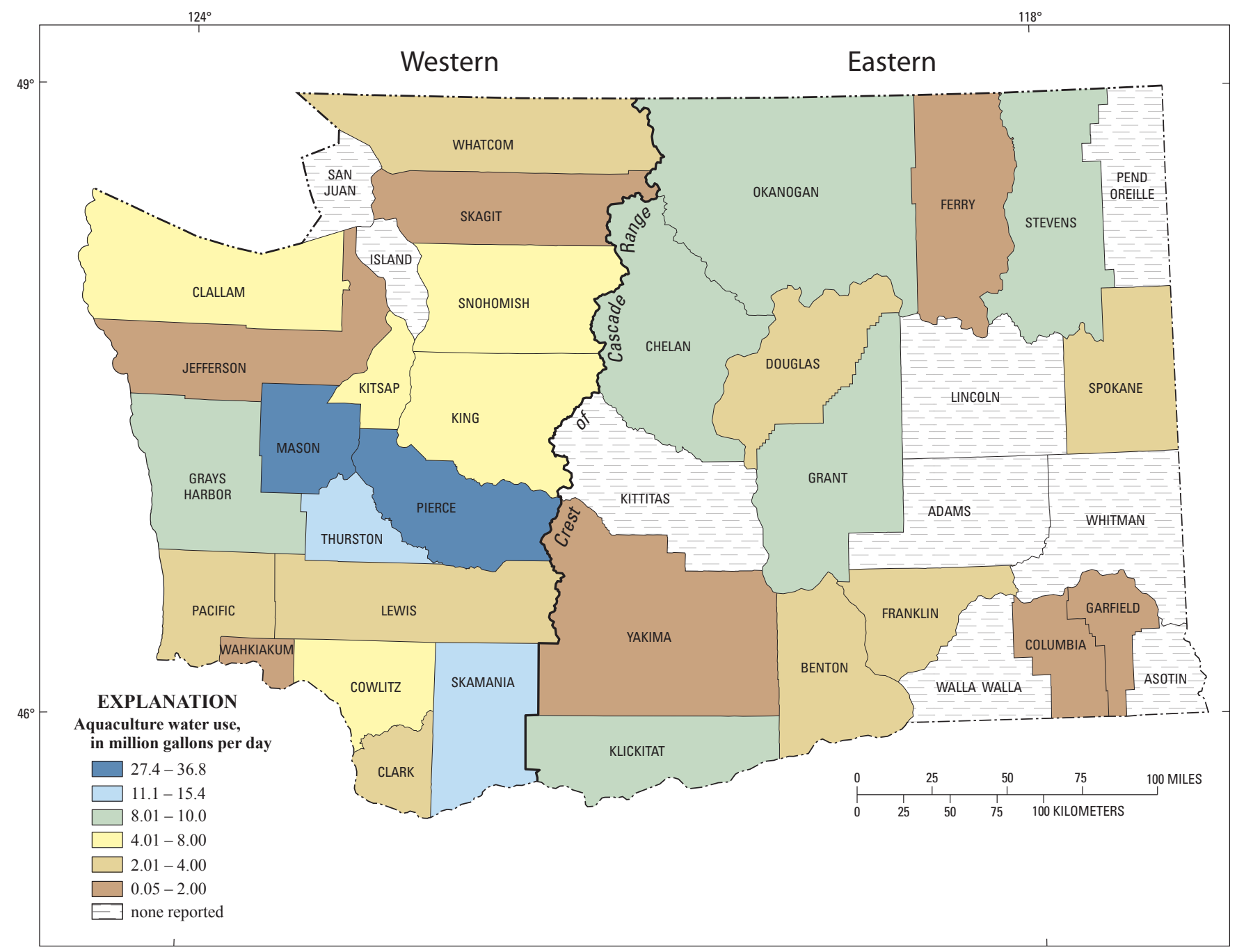

Figure 10. Estimated aquaculture water use, Washington, 2005. 


\section{Industrial}

Industrial water use in Washington for 2005 was estimated to be $520 \mathrm{Mgal} / \mathrm{d}$ (table 6), with individual countylevel use ranging from 0.01 to $123 \mathrm{Mgal} / \mathrm{d}$ (fig. 11). Publicsupplied water accounted for 13 percent $(66.0 \mathrm{Mgal} / \mathrm{d})$, selfsupplied surface water accounted for 67 percent (346 Mgal/d), and self-supplied groundwater accounted for 21 percent (107 $\mathrm{Mgal} / \mathrm{d}$ ) of the total State use. In terms of production hours worked, the three major industrial groups in Washington in 2005 were manufacturing of transportation equipment, wood products and paper, computer and electrical products, and the fabrication of various metallic and non-metallic products.

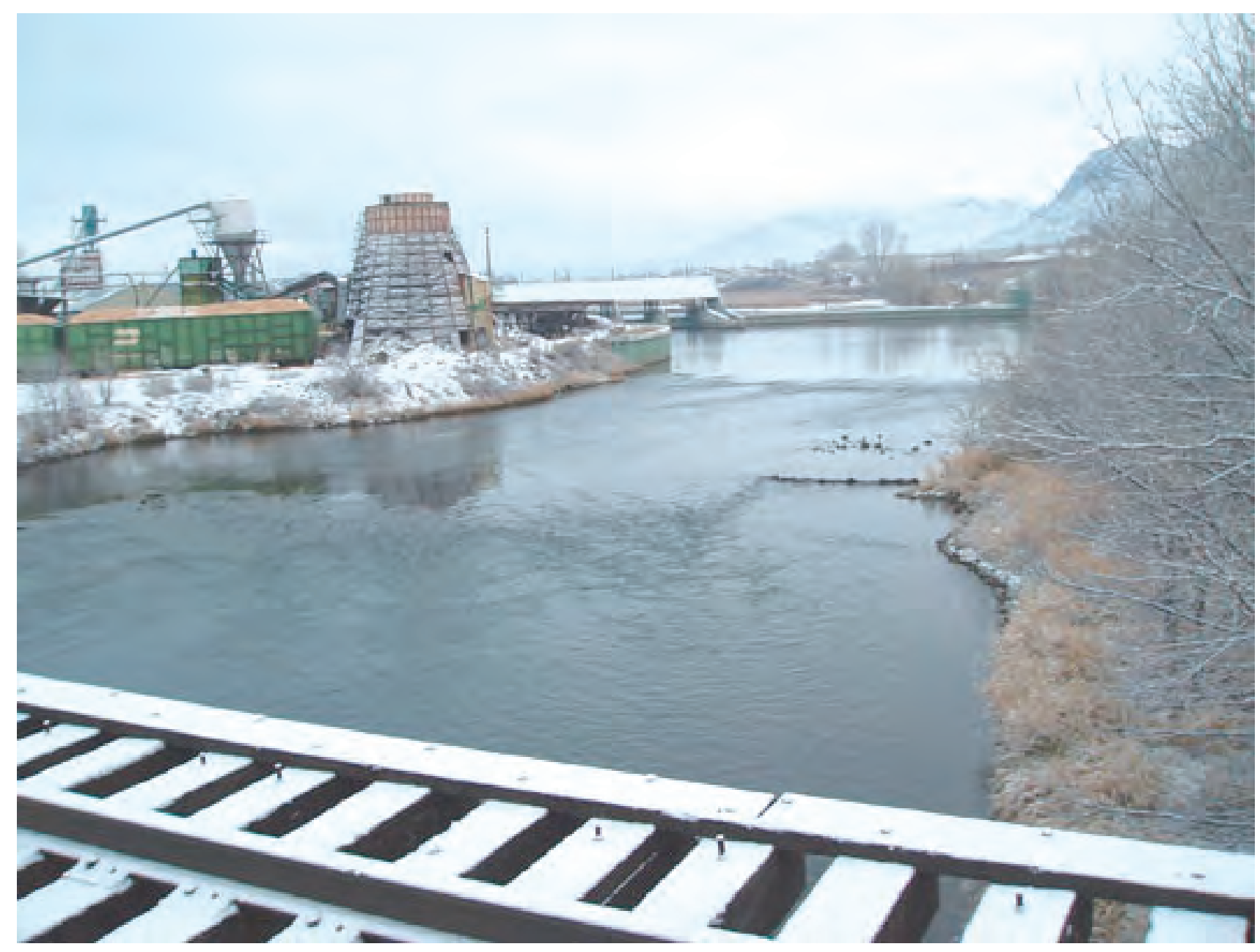

The production of lumber and other wood products continues to be a major use of water for industrial purposes in Washington State in 2005. Photograph courtesy of U.S. Geological Survey, Washington Water Science Center, accessed January 16, 2009, at http://wa.water.usgs.gov/cgi/ adr_photo.cgi?station $=12439500 \&$ photo $=\_3$ 
Table 6. Estimated industrial and mining water use, by source and county, Washington, 2005.

[Values may not add up to total due to independent rounding. All values in million gallons per day]

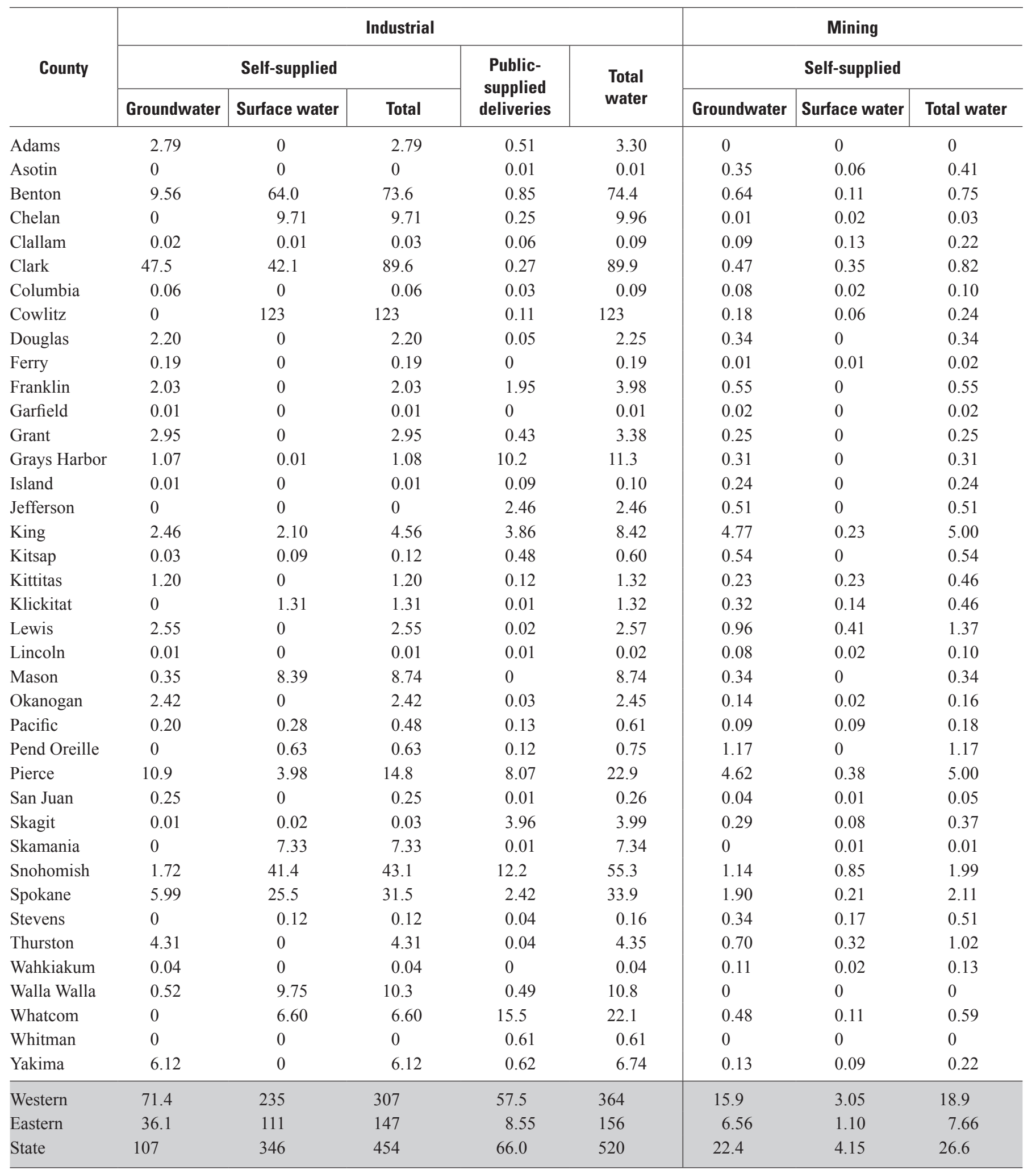




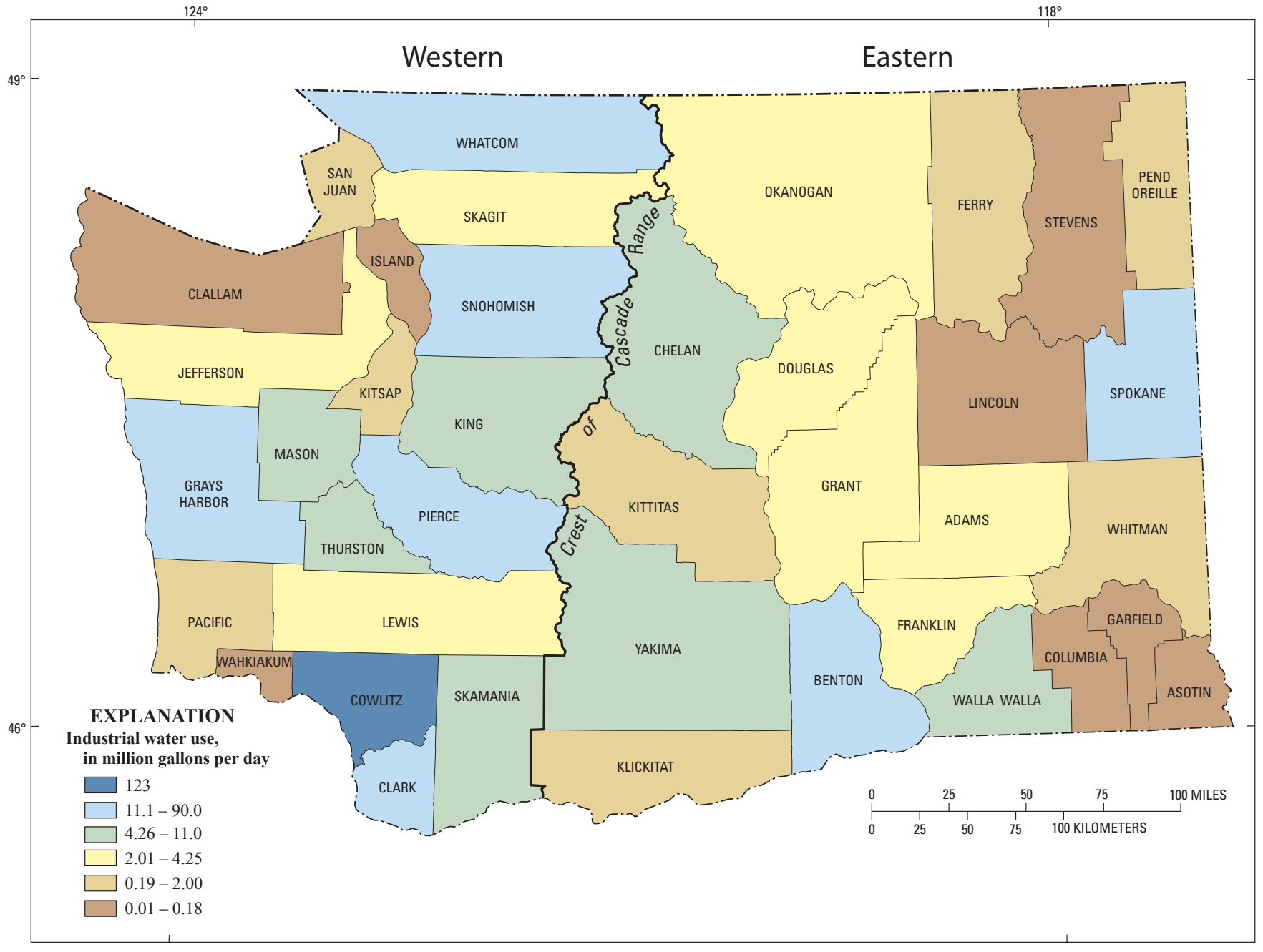

Figure 11. Estimated industrial water use, Washington, 2005. 


\section{Mining}

Mining water use in Washington for 2005 was estimated to be $26.6 \mathrm{Mgal} / \mathrm{d}$ (table 6), and county-level use was estimated to range from 0.01 to $5.00 \mathrm{Mgal} / \mathrm{d}$ (fig. 12). Selfsupplied surface water accounted for 16 percent $(4.15 \mathrm{Mgal} / \mathrm{d})$ and self-supplied groundwater accounted for the remaining 84 percent (22.4 Mgal/d) of total mining water use in the State. County-level mining water use estimates ranged from 0.01 to $5.00 \mathrm{Mgal} / \mathrm{d}$. Nearly all of the mining water use in

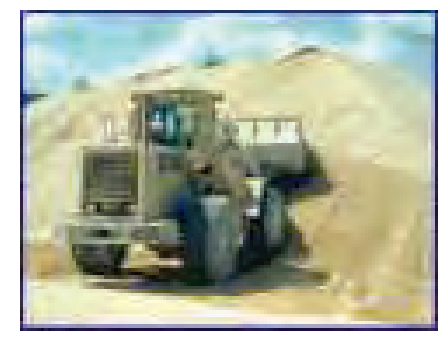
Typical gravel mine operation in Washington State, 2005. Photograph by Eric de Place, June 20, 2006. Copyright by Sightline Institute, Seattle, Washington; used with permission, accessed January 16 , 2009, at http://www.sightline.org/ images/blog2006/gravel-mine/view Washington was for the mining and quarrying of sand, gravel, stone, and other non-metallic minerals.

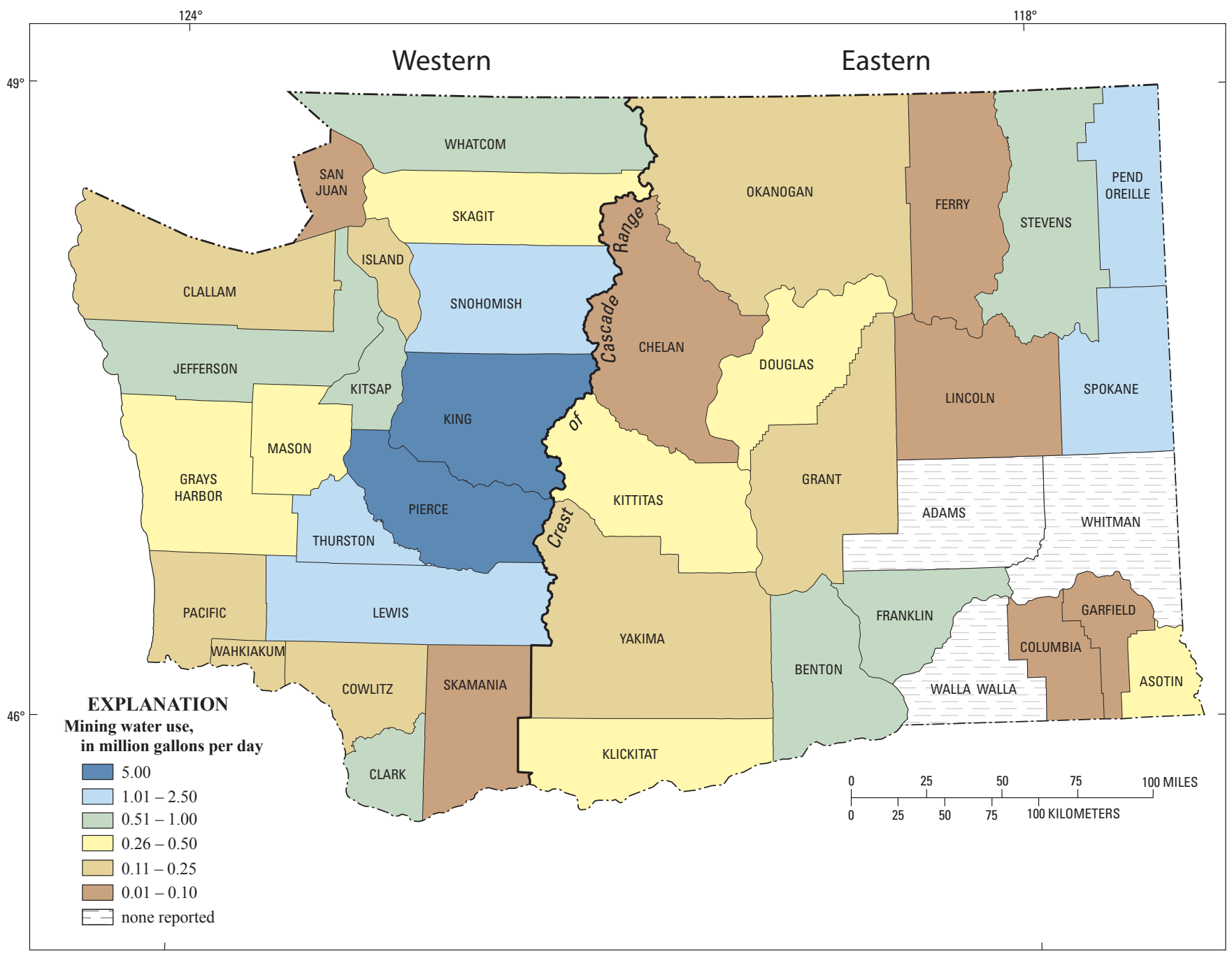

Figure 12. Estimated mining water use, Washington, 2005. 


\section{Thermoelectric Power}

Thermoelectric power water use in Washington in 2005 was estimated to be $456 \mathrm{Mgal} / \mathrm{d}$ or about 8 percent of total water use in the state. Public-supply deliveries accounted for 0.2 percent $(0.81 \mathrm{Mgal} / \mathrm{d})$ of the total thermoelectric power water use in Washington. Self-supplied surface water accounted for the remaining 99.8 percent $(455 \mathrm{Mgal} / \mathrm{d})$ of the total thermoelectric power water use in Washington. There was no reported use of groundwater or of saline surface water for thermoelectric purposes in the State in 2005. Regional and county-level use data are not included in this report to avoid disclosing data for the individual thermoelectric power facilities in Washington.

\section{Summary}

As used in this report, water use refers only to the offstream use of freshwater for public supply, domestic, irrigation, livestock, aquaculture, industrial, mining, and thermoelectric power purposes in the State of Washington during 2005, and does not include water used for instream purposes or offstream uses beyond those listed. Likewise, the term 'total water' refers only to the sum of the individual estimates for the specified uses and should not be confused with the absolute total amount of water used for all purposes in Washington.

Total freshwater use (public-supplied plus self-supplied) in Washington for 2005 was estimated to be about $5,780 \mathrm{Mgal} / \mathrm{d}$. Fresh surface water accounted for 74 percent (4,280 Mgal/d). Fresh groundwater accounted for the remaining 26 percent $(1,490 \mathrm{Mgal} / \mathrm{d})$ of the total freshwater use.

Total saline water use was estimated to be $33.2 \mathrm{Mgal} / \mathrm{d}$, all of which was from surface-water sources in western Washington. Nearly all saline water use was for industrial purposes in Pierce (21.4 Mgal/d), Grays Harbor (6.6 Mgal/d), and Jefferson (5.2 Mgal/d) Counties. Various public-supply systems withdrew and desalinized $0.05 \mathrm{Mgal} / \mathrm{d}$ of seawater to augment freshwater supplies.

Public-supply water use was estimated to total $990 \mathrm{Mgal} / \mathrm{d}$ or about 17 percent of total water use in Washington in 2005. Surface water accounted for 46 percent ( $451 \mathrm{Mgal} / \mathrm{d}$ ) and groundwater accounted for the remaining 54 percent (539 Mgal/d) of the total use. The per-capita rate of publicsupply water use was estimated to be $181 \mathrm{gal} / \mathrm{d}$ while the county-level rates ranged from 106 to $899 \mathrm{gal} / \mathrm{d}$.
Domestic water use was estimated to be $648 \mathrm{Mgal} /$ day or about 11 percent of total water use in the state in 2005. Public-supplied water accounted for 87 percent (562 Mgal/d) and self-supplied withdrawals of groundwater accounted for almost all of the remaining 13 percent $(86.0 \mathrm{Mgal} / \mathrm{d})$ of the total domestic water use. The per-capita rate of domestic use was estimated to be $103 \mathrm{gal} / \mathrm{d}$ while the county-level rates ranged from 72 to $210 \mathrm{gal} / \mathrm{d}$.

Irrigation water use was estimated to be $3,520 \mathrm{Mgal} / \mathrm{d}$ or about 61 percent of total water use in the state in 2005. Surface water accounted for 82 percent $(2,890 \mathrm{Mgal} / \mathrm{d})$ and groundwater accounted for the remaining 18 percent $(629 \mathrm{Mgal} / \mathrm{d})$ of the total use. The state-level irrigation application rate was estimated to be $2.14 \mathrm{ft} / \mathrm{yr}$ while the county-application rates ranged from 0.27 to $3.25 \mathrm{ft} / \mathrm{yr}$.

Livestock water use was estimated to be $30.7 \mathrm{Mgal} / \mathrm{d}$ or about 0.5 percent of total water use in Washington in 2005. Surface water accounted for 32 percent $(9.82 \mathrm{Mgal} / \mathrm{d})$ and groundwater accounted for 68 percent $(20.9 \mathrm{Mgal} / \mathrm{d})$ of the total livestock water use in the State.

Aquaculture water use was estimated to be $211 \mathrm{Mgal} / \mathrm{d}$ or about 4 percent of total water use in Washington in 2005. Surface water accounted for 59 percent (124 Mgal/d) and groundwater for the remaining 41 percent $(86.7 \mathrm{Mgal} / \mathrm{d})$ of the total State use.

Industrial freshwater use was estimated to be $520 \mathrm{Mgal} / \mathrm{d}$ or about 9 percent of total freshwater in the State in 2005. Public-supplied water accounted for 13 percent $(66.0 \mathrm{Mgal} / \mathrm{d})$; self-supplied withdrawals of fresh surface water accounted for 67 percent (346 Mgal/d); and self-supplied groundwater accounted for 21 percent (107 Mgal/d) of use.

Mining water use was estimated to be $26.6 \mathrm{Mgal} / \mathrm{d}$ or about 0.5 percent of the total water use in the State in 2005. Self-supplied surface water accounted for 16 percent (4.15 Mgal $/ \mathrm{d})$ and self-supplied groundwater accounted for the remaining 84 percent $(22.4 \mathrm{Mgal} / \mathrm{d})$ of total mining water use in the State.

Thermoelectric power water use was estimated to be $456 \mathrm{Mgal} / \mathrm{d}$. Thermoelectric water use was about 8 percent of total water use in Washington in 2005. Public-supply deliveries accounted for 0.2 percent $(0.81 \mathrm{Mgal} / \mathrm{d})$ of the total thermoelectric power water use in Washington. Self-supplied fresh surface water accounted for the remaining 99.8 percent ( $455 \mathrm{Mgal} / \mathrm{d})$ of the total thermoelectric power water use in Washington in 2005. 


\section{References Cited}

Dion, N.P., 1985, Washington ground-water resources, in U.S. Geological Survey, National Water Summary 1984 Hydrologic events, selected water-quality trends, and ground-water resources: U.S. Geological Survey WaterSupply Paper 2275, p. 433-438.

U.S. Department of Agriculture, 2003a, Census of agriculture (2002): National Agricultural Statistics Service, accessed April 26, 2006, at : http//www.nass.usda.gov/census/ census $02 /$ volume $1 / \mathrm{wa} / \mathrm{indes} 1 . \mathrm{htm}$

U.S. Department of Agriculture, 2003b, Farm and ranch irrigation survey (2003) National Agricultural Statistics Service, accessed April, 26, 2006, at http://www.agcensus. usda.gov/Publications/2002/FRIS/index.asp

U.S. Department of Commerce, 2005, 2002 Economic census: Geographic Area Series: Washington: accessed January 17, 2007, at : http://www.census.gov/econ/census02

U.S. Geological Survey, 2004, Estimated domestic irrigation and industrial water use in Washington, 2000, U.S. Geological Survey Scientific Investigations Report 2004$5015,16 \mathrm{p}$.

Williams, J.R., 1986, Washington surface-water resources, in Moody, D.E., Chase, E.B., and Aronson, D.A., National Water Summary 1985-Hydrologic events and surfacewater resources: U.S. Geological Survey Water-Supply Paper 2300, p. 473-478.

\section{U.S. Geological Survey Water-Use Reports}

\section{(in order of date published)}

U.S. Geological Survey, 1951, Estimated use of water in the United States in 1950: U.S. Geological Survey Circular 115, $13 \mathrm{p}$.

U.S. Geological Survey, 1957, Estimated use of water in the United States in 1955: U.S. Geological Survey Circular 398, $18 \mathrm{p}$.

U.S. Geological Survey, 1961, Estimated use of water in the United States in 1960: U.S. Geological Survey Circular 456, $26 \mathrm{p}$.
U.S. Geological Survey, 1967, Municipal, industrial, and irrigation water use in Washington, 1965: U.S. Geological Survey Open-File Report, 13 p.

U.S. Geological Survey, 1968, Estimated use of water in the United States in 1965: U.S. Geological Survey Circular 556, $53 \mathrm{p}$.

U.S. Geological Survey, 1971, Municipal, industrial, and irrigation water use in Washington, 1970: U.S. Geological Survey Open-File Report, 21 p.

U.S. Geological Survey, 1972, Estimated use of water in the United States in 1970: U.S. Geological Survey Circular 676, $37 \mathrm{p}$.

U.S. Geological Survey, 1977a, Estimated use of water in the United States in 1975: U.S. Geological Survey Circular 765, $39 \mathrm{p}$.

U.S. Geological Survey, 1977b, Municipal, industrial, and irrigation water use in Washington, 1975: U.S. Geological Survey Open-File Report 77-308, 34 p.

U.S. Geological Survey, 1983, Estimated use of water in the United States in 1980: U.S. Geological Survey Circular 1001, 56 p.

U.S. Geological Survey, 1988, Estimated use of water in the United States in 1985: U.S. Geological Survey Circular 1004, 82 p.

U.S. Geological Survey, 1993, Estimated use of water in the United States in 1990: U.S. Geological Survey Circular 1081, 76 p.

U.S. Geological Survey, 1998, Estimated water use in the United States in 1995: U.S. Geological Survey Circular 1200, $71 \mathrm{p}$.

U.S. Geological Survey, 2004a, Estimated water use in the United States in 2000: U.S. Geological Survey Circular 1268, 46 p.

U.S. Geological Survey, 2004b, Estimated domestic, irrigation, and industrial water use in Washington, 2000: U.S. Geological Survey Scientific Investigations Report 2004-5015,16 p. 


\section{Glossary}

The concepts and terms in this glossary are modified from the U.S. Geological Survey's National Handbook of Recommended Methods for Water Data Acquisition, available on the Web at $</ /$ water.usgs.gov/pubs/chapter11/chapter11M.html $>$, and from its guidelines for preparation of State water-use estimates.

Aquaculture: Water used in the rearing of organisms that live in water, such as fish, shellfish, and algae, within a confined space and under controlled feeding, sanitation, and harvesting procedures.

Class A system: A public water-supply system that has a full-time service population of at least 25 people or that has at least 15 connections.

Class B system: A public water-supply system that has a full-time service population of less than 25 people or that has fewer than 15 connections.

Domestic (residential): Water used for household purposes such as drinking, food preparation, bathing, washing clothes and dishes, flushing toilets, car washing, and watering lawns and gardens.

Freshwater: Water that contains less than $1,000 \mathrm{mg} / \mathrm{L}$ of dissolved solids; generally, more than $500 \mathrm{mg} / \mathrm{L}$ of dissolved solids is undesirable for drinking and many industrial uses.

Groundwater: Generally all subsurface water as distinct from surface water; specifically, that part of the subsurface water in the saturated zone (a zone in which all voids are filled with water).

Industrial: Water used for industrial purposes such as fabrication, processing, washing, and cooling, and includes such industries as steel, chemical and allied products, paper and allied products, smelting, and petroleum refining.

Instream use: Water that remains in a surface or groundwater source during use.

Irrigation: Artificial application of water on lands to assist in the growing of crops and pastures or to maintain vegetative growth in recreational lands such as parks and golf.

Livestock: Water for livestock watering, feedlots, dairy operations, and other on-farm needs in the rearing, cleaning, and processing of all animals other than fish or shellfish.
Mining: Water used for the extraction of minerals occurring naturally including solids, such as coal and ores; liquids, such as crude petroleum; and gases, such as natural gas. Water use associated with quarrying, well operations (dewatering), milling (crushing, screening, washing, floatation, and so forth), and other preparations customarily done at the mine site or as part of mining activity also are included. Mining uses do not include water used in processing, such as smelting, refining petroleum, or slurry pipeline operations; these uses are included in industrial water use.

Offstream use: Water withdrawn or diverted from a groundwater or surface-water source for a specific use.

Per capita: The average amount of water used per person during a standard time period, generally per year.

Public water-supply system: A publicly or privately owned facility that supplies water to a variety of users such as cities, towns, rural water districts, mobile-home parks, Indian reservations and military instillations.

Residential: see Domestic

Saline water: Water that contains more than 1,000 milligrams per liter of dissolved solids.

Self-supplied: Water withdrawn from a surface-water or a groundwater source by an individual user and not obtained from a public-supply system.

Surface water: An open body of water, such as a stream or lake.

Thermoelectric: Water used in the process of the generation of thermoelectric power.

Water use: (1) In a restrictive sense, the term refers to water that is actually used for a specific purpose, such as for domestic use, irrigation, or industrial processing. (2) More broadly, water use pertains to human's interaction with and influence on the hydrologic cycle, and includes elements such as water withdrawal, distribution, consumptive use, wastewater collection, and return flow.

Withdrawal: Surface water or groundwater removed from the natural hydrologic system for use. 
Estimated Water Use in Washington, 2005

This page intentionally left blank. 
Publishing support provided by the U.S. Geological Survey Publishing Network, Tacoma Publishing Service Center

For more information concerning the research in this report, contact the Director, Washington Water Science Center

U.S. Geological Survey, 934 Broadway - Suite 300

Tacoma, Washington 98402

http://wa.water.usgs.gov 
总

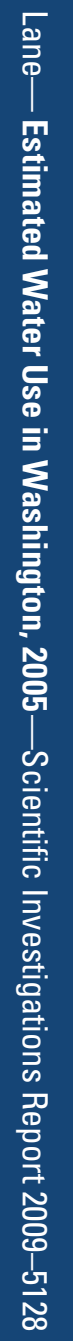

